Uşak Üniversitesi Sosyal Bilimler Dergisi

$2015,8 / 2$

\title{
Sosyolojik Bağlamda Müzik ve Kimlik: Karabük Üniversitesi Örneği
}

Adem SAĞIR*

Barış ÖZTÜRK ${ }^{* *}$

\section{Öz}

Müzik, bir sanat biçimi olarak temelde insanın zevklerine ve estetik kaygılarına hitap eder. Müzik, içerdiği farklı anlamlarla da toplumsal tutumların ve pratiklerin önemli bir yansıması olarak ortaya çıkar. Bu bağlamda müzik, toplumsal bir kimlik olarak bireylerin davranış pratiklerinde önemli bir yere karşılık gelir. Bu karşılık, aynı zamanda estetik kaygıların kültürel bir süreç sonucunda ortaya çıkıyor olması nedeniyle de özellikle anlamlıdır. Toplumsal koşullara uygun olarak farklı biçimlerde ortaya çıan müzik, bireylerin kendilerini ifade etmeleri için kullandığ 1 önemli sosyal araçlardan birisidir. Değişen sosyal şartlar, müzik tarzlarını ve bireylerin müzik tercihlerini de etkilemektedir. Böylece müzik, sosyal kimliklerin yansıdığı sosyolojik betimleme alanına dönüşmektedir. Çalışma, bu bağlamdan hareketle müziğin, toplumsal kimlikler üzerindeki etkisini sosyolojik bağlama oturtmuştur. Çalışmanın temel amacl, sosyalleşme biçimleriyle kendilerini dışa vuran bireylerin müziği bir araç olarak nasıl kullandıklarını tespit etmektir. Çalışmanın evreni Karabük Üniversitesi olarak belirlenmiştir. Çalışma sonuç olarak gençler için müziğin ifade ettiği anlamları sosyolojik olarak çözümlemiş olması bakımından dikkate değerdir.

Anahtar Kelimeler: Sosyalleşme, Sosyal Kimlik, Kültürel Kimlik, Müzik, Karabük Üniversitesi.

\section{The Context of Sociological Identity and Music: The Case of Karabuk University}

\begin{abstract}
Music, as an art, basically addresses to the pleasures and aesthetic concerns of the people. Music with its different meaning shows up as an important reflection of the social practical. In this context music as a social identity, has an important role. Music, emerging in different ways according

* Yrd. Doç. Dr., Karabük Üniversitesi Sosyoloji Bölümü, Genel Sosyoloji ve Metodoloji Ana Bilim Dalı, ademsagir@karabuk.edu.tr

** Karabük Üniversitesi Sosyal Bilimler Enstitüsü Sosyoloji Ana Bilim Dalı, barıskeman35@hotmail.com
\end{abstract}


to the social conditions, is an important social tool used to express themselves. Changing social conditions affect the music style and affects individuals' music preferences. So music transforms into a space that reflects social identity. This study has sat the impact of music on sociological context. The main purpose of the study is to determine how people, who outward themselves with their form of socialization, use it as a tool. The study of the universe is Karabük University. Sociological analysis of the study is significant with the results which reflect the meaning of music for the youth.

Key Words: Socialization, Social Identity, Cultural Identity, Music, Karabük University.

\section{Küreselleșen Dünyada Kimliklerin Duygusal İfade Biçimleri}

Küreselleşmenin yerel kimlikler üzerinde yarattığı etkiler, toplumların kendilerini sorguladığı ve yeniden inşa ettikleri bir alanın ortaya çıkmasına neden olmuştur. Ortadan kalkan sınırlar ve bu sınırların birleştirdiği yeni toplumsal alanlar bireyleri, kendilerini ifade edebildikleri yeni bir arayışın içerisine sokmuştur. Küreselleşmenin getirdiği kitlesellikte birleşen bireyler, aynı zamanda kendi ürettikleri kişisel alanlarla da özgürleşmeye veya yerelleşmeye çalışmaktadırlar. Müzik, bu bağlamda bireylerin kendilerini ifade etmeye çalıştıkları arayışın bir karşılığı olarak düşünülebilir. Dünyanın giderek artan rasyonelliği içerisinde, müzik bireylerin kendilerini ifade ettikleri "a-rasyonel" biçimlerin kendisine denk düşmekte ve sosyal etkileşimlerle yeni içerikler kazanmaktadır. Burada arasyonel kavramını tanımlayan şey, modern toplumun ürettiği "gerginlikler"ten kaçışı betimleyen "toplumdışılık" halidir. Toplumdışı olma hali, bireylerin sosyal hayatta yoruldukları zamanlarda, kendilerini içerisine attıkları "dinlenme" ve "düşünme" alanlarına gönderme yapmaktadır. Bu alanlar, aynı zamanda bireylerin modern hayata karşı "direnme duraklarımı" temsil etmektedir. Günümüzde küreselleşmenin meydana getirdiği en belirgin değişimin sosyal hayatın her alanında bir "direniş kültürünü" ortaya çıkartması olduğu dikkate alındığında müziğin de bir direniş olabileceği iddiası anlaşılır durmaktadır. Aslında müziğin yukarıda bahsi geçen bu rahatlatıcı işlevi, tarih boyunca hastalıkların tedavi edilmesi sürecinde kullanılmıştır. Örneğin Türk-İslam kültüründe "müzikoterapi faaliyetlerinin ve özellikle hastanelerde müzik kullanarak tedavi yöntemlerinin ilk defa 9.yy'da başladığ ve 18.yy'a kadar bu konuda büyük ilerlemeler olduğu görülmüştür" (Somakc1, 2003: 138). Aynı yöntem, Avrupa'da II. Dünya Savaşı yıllarında sistematik bir şekilde uygulanmaya başlanmıştır. 
Müzik, çoğunlukla insanın duygu ve düşüncelerini kulağa hoş gelen ahenkli sözlerle ve notalarla ifade ettiği bir sanat olarak betimlenir. Müzik, aynı zamanda, bireyin duygu ve düşünceleri geniş kitlelere ulaştırabilen ve kendisiyle aynı ruh halinde olan bireyler arasında bir sosyal ağ oluşturabilen bir araçtır. Bu sosyal ağ, benzer müzik tarzını dinleyen bireylerin oluşturduğu bir alanı ifade eder. Bu alan, zevkler, beğeniler, duygusal heyecanlar, coşkular ve sosyal çıkarımların kendisinde yansımalar bulduğu yerdir. Bahsi geçen sosyal ağ, aynı zamanda farklı demografik özelliklerdeki bireyleri, ortak kolektif bilinç etrafında toplayan bir sosyalleşmenin de kendisidir. Konserler, fan grupları, sosyal medyada üye olunan gruplar, tercih edilen mekânlar, internet sözlüklerinde tanımlanan alanlar, sosyal medyanın facebook ve twitter dışında kalan araçları gibi birçok alanda müziğin, bahsi geçen sosyalleşme aracı oluşuna gönderme yapmaktadır. Müziğin sosyalleştirici gücü temelde iki farklı kimlik düzeyini ifade eder. Bunlardan birincisi küreselleşen dünyada evrensel olan müzik kodları üzerinden kurulan birliktelik ve tanımlamalardır. Aynı sanatçıları dinleyen uzaktaki insanlar için sınırların ortadan kalktığı ve ortak bir alanda soyut olarak sosyalleştikleri görülür. İkincisi ise yerel kültür içerisinde değişmeden kalan veya yeni biçimlerle ortaya çıkan müzik kodlarıdır ki bu kodlar ise farklı bir sosyalleştirme aracı olarak müziğin kimlikler üzerindeki etkisini göstermektedir.

$\mathrm{Bu}$ sosyal ağ aynı zamanda bireyin bir tüketici olarak müzik karşısındaki duruşunu ifade eder. Müziğin tüketilme biçimleri, aynı zamanda bireyin kimlik olarak kendini tanımlamasını da içerir. Sosyal ağ sayesinde müzik dinleyicileri, kendilerine ortak bir ağ inşa eder ve bu ağ etrafında bir sınıf oluşturarak hayatlarını bu sınıf etrafında şekillendirir. Örneğin punk, rock ve arabesk, bir müzik türü olmaktan ziyade başlı başına bir kültürün temsil biçimlerine dönüşmektedirler. Fertler, bu müzik kültürü içerisinde kendi dünyalarını tanımlamakta ve yaşamlarını bu kültür içerisinde anlamlandırmaktadırlar. Bu sinıflar "yüzergezer kalabalıklar" olarak kendilerini belirler ve genelde kendilerini ifade ettikleri müzik alanında bir tüketici rolüyle sosyal ilişkilerini devam ettirirler.

Rock müzik dinleyenlerin küpe takmaları, punkların kendilerine has giyinme tarzları, arabesk dinleyenlerin kollarında ya da vücutlarda jilet izleri, müziğin dış kimliklere yansımış göstergeleridir. Burada kuşkusuz sosyolojik olarak sembollerin ve simgelerin bireylerin kimliklerine yansıdığı biçimlere gönderme yapılmaktadır. Böylece aynı formayı giyince belli bir sosyal gruba ait olduğunu belirginleştiren taraftarlar gibi, aynı müzik tarzını dinleyenler de birbirleriyle etkileşim içerisinde olan gruplara 
dönüşmektedirler. $\mathrm{Bu}$, aynı zamanda bir sosyal sermaye oluşumun da bir göstergesidir. Burada günümüz toplumlarında sıkça güncellenen "yeni cemaatler" olgusuna da atıf yapmak mümkündür; çünkü oluşan sosyal sermayeyi betimleyen şeyler, yoğunlukla yeni cemaatlerin nitelikleriyle doğrudan ilişkilidir.

Sennett (2005: 145), insanların bugünlerde bir cemaat üyesi olmaya özenmelerini; "esnekliğin belirsizlikleri, köklü bir güven ve bağlllık duygusunun olmayışı, en önemlisi de kişinin kendisinden bir şey yapmaması, işi aracılığıyla hayatını çizememesinin sonucu" olarak açıklamaktadır. Kuşkusuz, müzik söz konusu olduğunda bu durum, bütün türler için geçerli olmayabilir. Ancak yukarıda bir "yaşam kültürünü" ifade ettiği varsayılan müzik tarzları, bu bağlamda dikkate değerdir. Yelken (1999: 263), Sennett ile paralellikte, sınırlı sorumluluk cemaati olarak tanımlanan cemaatlerin, geleneksel cemaat yapılarından oldukça farklı olduğuna gönderme yapmaktadır. Yelken'e göre yeni cemaatler, topraktan kopmuşlardır ve artık sadece yerel yerleşimler olarak değil, bir araya gelme, sosyal ağ oluşturabilme ve kültürel iletişim biçimlerine göre algilanmaktadır.

Zygmunt Bauman'ın Maffesoli'nden aktardığ kabile" ya da "postmodern kabile"si konuyu ayn perspektiften farklı bağlamlara taşımıştır. Bauman (2003:318)'a göre neo-tribe-postmodern kabile, "doğru ve yanlış ya da güzel ve çirkin konusunda sadece kabile hakikatlerini ve kabile kararların tanıyan bir kabile dünyasıdır. Fakat bu aynı zamanda da, çok hayatsal bağlamlarda orijinal kabile antikitesinden ayrilan yeni bir kabile dünyasıdır." Burada kuşkusuz eski kabilelere kıyasla daha gevşek bir örgütlenme söz konusudur. Bauman, postmodern kabilelerin, somut olarak da toplandıkları hızla dağılmalarına ve üyelikten görece kolay bir biçimde çıkabilmesine işaret ederek geçmişe kıyasla farklarını betimlemiştir. Bauman için bu kabileler, "çok anlamlı", "çok işlevli" ve "çok sonlu" kabilelerin aksine bir eylemek tipinde ve bir grup sembolde uzmanlaşmışlardır (Bauman, 2003: 319; Warde, 2005: 62-63). Bu betimleme, çalışmanın içeriğini doldurması bakımından müzik etrafında oluşan sosyal ağların gerçekliği için de kullanılabilir durmaktadır. Batı'da müzikle ilgili yapılan çalışmalarda, "altkültür" kavramının müzik topluluklarını açıklamakta yetersiz kaldığı ifade edilirken "neo-tribe" kavramının ise tam bu toplulukları açılamakta yeterli olduğu vurgusu yapılmaktadır. Bennett (2006), özellikle geçici kimliklerin doğasının tanımlanması için ideal olduğuna vurgu yapmaktadır. Maffesoli (1996)'nin betimlediği bir şekilde orijinal haliyle neo-tribe, "klasik ağların katılaşmış yapıları olmadan, ortamına göre şekil alan bir ruh hali" olarak kabul görmüştür. Burada özellikle müziği üretenle-tüketen arasında açllan makasa da bir gönderme yapılmaktadır. Müzik etrafında oluşan ağlar, aynı 
zamanda bir tüketici olarak bireyim kimliksel dışa vurumlarına karşılık gelmektedir. Kuşkusuz burada yavaşça müziğin toplumla ve doğal olarak da sosyolojiyle ilişkisine ulaşılmaktadır.

Aslında müziğin sosyolojik olarak önemi, bireylerin sanatsal üretimlerini sosyalleşme sürecindeki kazanımlarına göre yapmalarıdır ki bu kazanımlar kültürel yapı ile doğrudan alakalıdır ve farklı sosyo-kültürel yapı özelliklerini farklı müzik tarzlarıyla göstermelerinden ileri gelmektedir. Müzik-toplum etkileşimi bu bağlamda, müzik eserinin yaratıcısı, yorumcusu ve hedef kitlesini oluşturan bireyler ve geniş anlamda kitleler arasında gerçekleşen bir süreci ifade etmektedir. Müzik eseri üreticisi ve yorumcusu bireyler dinleyici kitleden farklı olarak, bu süreçte hem yaratıcı özne olarak hem de alıcı pasif nesne olarak ele alınabilmektedir. İçinde yaşadığımız dönemdeki teknolojik gelişmeler- kitle iletişim araçlarındaki gelişmeler- yaratıcı yorumcu ve hedef kitle üçlemesinde bazı unsurları daha da ön plana çıkarmış durumdadır. Müzik bireyler için, vazgeçilmez bir eğlendirici öğe olmanın yanında, artık bireyin mensubiyetlerini gösteren bu anlamda kimliğini ifade eden simgeler-semboller bütününe dönüşmüştür.

Müziğin toplumsal işlevleri konusunda belli bir sınır çizmek gerektiğinde, karşımıza müziğin sosyolojik boyutu çıkmaktadır. Söz konusu toplumsal işlevlerden birini, müziği aynı tür müzik dinleyicisi, icracısı bireyler arasında bir ağ kurma aracı olması ifade ederken diğerini kişiler arası duygu, düşünce, tasarım, izlenim alışverişi sağlamak ifade etmektedir (Sağır vd., 2007: 359). Bu bağlamda derin ve kapsamlı sanat alanı olan müzik, bireyleri ve dolayısıyla toplumu birçok açıdan etkilemekte ve yönlendirmektedir (Şenocak, 2005: 278). Müziğin insan hayatında bu kadar kapsamlı ve derin etkileri, sosyolojik olarak araştırılmasını zorunlu kılmaktadır.

Bu noktalardan hareketle hazırlanmış olan çalı̧̧ma, müzik-toplum arasındaki etkileşim biçimlerinden yola çıarak bir kimlik analizi yapmayı hedeflemiştir. Örneklem olarak kendisine Karabük Üniversitesi öğrencilerini seçmiştir. Çalışmanın merkezine, gençlerin dinledikleri müzik tarzlarıyla yaşam biçimleri arasındaki ortaklıkları ve müziği kimliklerinin ifade biçimlerine nasıl yansıttıkları yerleştirilmiştir. Amaç, müziğin bir sosyal ağ olma özelliğini sosyal kimlik kavramı üzerinden okuyarak bir müzik sosyoloji denemesi yapmaktır.

\section{Müziğin Sosyolojik Görünümleri}

Müzik, dünya dillerine Yunanca "mousike" veya "mousa"dan geçmiş bir kelimedir ve dünyanın her yerinde aynı anlamı taşımaktadır. Kelimenin mitolojik bir kavram olan "musica" sözcüğünden geldiği kabul edilmektedir. 
Araştırmacılar, kelimenin etimolojisinin "muse-melek" anlamına geldiğini iddia etmektedir. Mitolojiye göre Yunanlıların en büyük tanrısı Zeus'un kızları sayılan dokuz peri kızına "mousa" (müz) adı verilirdi. Eski Yunanlılar, peri kızlarının tüm dünyanın güzelliklerini ve ahengini düzenlemekle görevli olduklarına inanırlardı (Uçan ve Ovayolu, 2006: 15).

Türkçe'de müzik karşılı̆̆ında musiki kelimesinin de yaygın bir kullanım alanı vardır. Uzakdoğu metinlerinde müzik, tonların bir verimi olarak tanımlanır ya da gök ve yer arasında bir ahenk olarak kabul edilir. Bu betimleme müziğe antropolojik ve bir özellik kazandırır. Müzik bu bağlamda düşünüldüğünde insan ile varlık arasında bağ kurulmasını sağlar. Müzik her ne kadar bu bağın kurulmasını sağlasa da tek tek insanları etkilemekten çok geniş bir alana yaygınlık kazandığı görülür. Toplumun hemen her yönünü etkilediği düşünüldüğünde, müzik olmadığında toplumda büyük bir boşluk olacağı da iddia edilebilir (Soykan, 2002: 30). Çünkü müzik, "acılar, sevinçler, kahramanlıklar, heyecanlar, özlemler, fikirler ve toplumsal alana dair her şey" (Ak, 1997: 5) müziğin konusudur. Ayrıca müziğin, "insanlık tarihi boyunca çeşitli kültürlerde insan duyguların etkilemek, kendini ifade etmek ve hastalıkları tedavi etmek amacı ile kullanıldığı" (Covington, 2001; Gençel, 2006; Uçan ve Ovayolu, 2006) da bilinmektedir. Toplumsal farklılıklar dikkate alınmaksızın müziğin bütün insanlar için ortak bir amaca karşlık geldiği görülmektedir.

Müzik özünde barındırdığı mistik özelliği ile diğer sanat tarzlarından her zaman daha önemli ve daha etkili olabilmiştir. Platon da müziği değerlendirirken işlevsel bir bakış açısı geliştirmektedir. Erdemli bir insan yetiştirmenin yolu müzik eğitiminden geçer. Söz, ritim ve makamın birleşmesinden oluşan müziğin etki gücünün biçimde çok fazla olduğunu belirterek, yiğit ve ölçülü davranışlar yerleştirecek biçimde oluşturulan müziğin kullanılması gerektiğini söyler (Platon, 1975: 34). Aristoteles'e göre de müzik Platon'da olduğu gibi, eğitim arac1, eğitimin bir bölümü ve ruhsal arınma (Aristoteles, 1975: 21) yoluyla kişiliğin oluşmasında önemli bir etkendir. Müzik, toplumların değer hedeflerinin kaynağına hitap eden en önemli sanat tarzlarından biridir. Toplum içindeki adet göreneklerden, yasalara kadar toplumdaki değer ve hedefleri kuşatan bir sanat dalı olması itibariyle de normatif bir sanat tarzıdır. Birçok düşünürün müzik tanımlamasında müziğin bir olgunluk ve eğitimin en önemli aracı olduğu belirtilmiş ve müziğe yüklenen anlam birçok derin anlama sahip olmuştur.

İnsana, bütün sanatlardan daha büyük bir kolaylık ve gücüyle ulaşan müzik, matematiksel bir mantık, disiplin, zamanı kullanma, susma, diyalog kurma, hareket etme ve ilişkiler sanatıdır. İnsan düşüncesinin ürünü olduğu kadar duygusal bir deşarj ürünü de olan müzik yaratıldığı dünya 
görüşüyle kısaca insan yaşamıla ve toplumla, bu bütün önceki sanatlar gibi sıkıca bağlıdır. Müzik yoluyla bir yandan günlük yaşamın üstüne çıkıp güç kazanırken bir yandan da birlikte yaşamın bütün kurallarını öğrenmek mümkündür (Selanik, 1996: 2). İnsanın kendisini müzikten soyutlaması mümkün değildir; çünkü müzik insanın duygularını rahatlıkla ifade ettiği alanlardan birisidir. Ayrıca kültürün en önemli unsurlarından biri olan müzik, sanatçıları ve müzik dinleyicileri arasındaki karşılıklı ilişki ile de yaşamakta ve bu ilişkiyi sosyal bir ağa dönüştürme gücüne de sahip olmaktadır.

Müzik belli bir kültür birikim sonucu oluşan ve toplumun bilincini yansitan bir araç olarak da kabul görmektedir. Çünkü toplum ve birey, kültürün bir parçası ve yansıması olduğundan müzik atmosferinde sanal anlamda bütünleşmeye yönelmektedir. Grup bilinci ve dayanışması, yalnızca melodilerin içindeki ritim yapıda kendini göstermektedir. Daha öncede vurgulandığımız gibi kültür ile sıkı ilişkileri vardır. Çünkü müzik, sadece dinlemesi güzel olan bir şey değildir. Tam tersine kültürün içine de gömülmüştür (Cook, 1999: 9). Müzik sadece teknik anlamda düşünülecek bir sanat tarzı değildir; çünkü müzik aynı zamanda kültürün en önemli öğelerinden birisidir. Bu özelliği sayesinde müzik eserleri üzerinden insanların olaylara bakış açısı, yaşam ile ilişkileri hakkında bilgi sahibi olmak mümkündür. Toplumla müzik arasındaki bu ilişkiden dolayıdır ki müzik, toplumsal koşullara uygun olarak sürekli değişmiş ve kendini yenilemiştir. Ortaya çıkan sorunlar yeni ifade tarzlarının ortaya çıkmasını gerekli kılmış, bireyler kendilerini ifade etmek için yeni tarzlar ifade etmişlerdir. İnsan müzikle etkileşim halinde olduğu zaman değişik davranış kalıpları kazanmaktadır.

Dinleme, benzetme, oynama, söyleme, mirıldama, çalma, yaratma, eleştirme, beğenme veya beğenmeme bu davranış kalıplarının bazılarıdır. $\mathrm{Bu}$ davranış kalıpları aynı zamanda bireyin müzikle girdiği sosyalleşme haritalarından bazılarıdır. Bu bilişsel durum beraberinde bir takım sosyal davranış süreçleri de getirir. Müzikle uyuma, Müzikle oynama, müzikle yürüme, müzikle eğlenme, müzikle dinlenme, müzikle çalışma, müzikle anlaşma ve müzikle kendini aşma davranışlarını bu bağlamda ele almak mümkündür (Sağır vd., 2007:360). Öğrencilerin derslerine müzik dinleyerek çalışmaları, yolculuk esnasında birçok yolcunun varacağı yere kadar müzik dinlemeleri, bazı insanların uyurken bile kulaklığı kulağından çıkarmamaları, engelli çocuklara, Alzheimer hastalarına ve akıl hastalarına uygulanan müzik terapileri güncel hayattan verilebilecek örneklerden bazılarıdır. 
Müzik eğitimi sadece genel müzik kültürü edinmeyi amaçlamakla kalmayıp, aynı zamanda eğitim çağındaki bireyler için diğer disiplinlerin eğitiminde etkili bir öğretme-öğrenme yöntemi ve biyo-psiko-sosyal bir canlı olan insan için de etkili bir 'kendini ifade etme' aracıdır. Özellikle genç nüfusun, yaş dönemlerinin doğal bir özelliği olarak da, kendilerini ifade etmede yaşadıkları sorunlar günümüz toplumlarının en çok uğraştıkları mücadele alanını teşkil etmektedir. Çünkü hayata yeni atılan gençler, umdukları, hayal ettikleri çevreyi ve düzeni kuramadıkları zaman (ki bu durum ülkemizde bu durum sıklıkla yaşanmaktadır) etkisiz kalmakta, içlerine kapanmakta, bazen kontrolsüz bir şekilde dışa açılmakta ve sınır durumuna gelip farklı arayışlara girebilmektedirler. Müzik çoğu zaman bu arayışlara çıkış noktası, bir çözülme ve anlatım aracı, kısaca bir ifade biçimi olmaktadır. Toplum içinde sorun yaşayan gençler, yaşadığı çevreye uyum gösteremeyen, kendilerini yeteri kadar ifade edemeyen gençlerin müziği bu süreçte bir kimlik algısı görmeleri müziğin bir dil olarak ne kadar güçlü bir sanat olduğunu gösterir. Bireylere kendini müzikle ifade etme fırsatının verilmesi, diğer pek çok yöntemden daha etkili olabilmektedir (Aksu, 2002: 73). Burada bir örnek olması bakımında rap müzik ve arabesk müzik türünden bahsetmek yerinde olur.

Bugünlerde sosyal medyada video sitelerine "amatör rap" kelimesi yazıldığında birçok amatör gencin kendi imkânlarıyla çektikleri video kliplere rastlamak mümkündür. Kliplerde görsel olarak dikkat çeken en belirgin temalar "salaş kıyafetler", "uyuşturucu madde kullanımına dair temalar", "benzer giyim ve davranışlarda birkaç insanın biraradalı̆̆ı", "saç şekilleri", "isyan tavirları", "mezarlk", "terk edilmiş barakalar", "metruk binalar", "alkol temaları", "açık araziler" veya "ormanlık alanlar" vb. olarak göze çarpmaktadır. Arabesk müziğin postmodern biçimlerde karşımıza çıtığ1 "arabesk-rap", görselliklerin yanında kullandığı temel içeriklerle de özellikle gençlerin kullandığ temalar ise; "kavuşulamayan sevgili", "aldatılan sevgili", "ölüm", "depresyon", "kavga", "özlem", "hasret", "yasak aşk", "kadere isyan", "dert", "keder", "acı", "sevgili uğruna ölme, öldürülme veya öldürme", "meydan okuma", "sisteme veya düzene direnme" $v b$. şeklinde sıralanabilmektedir. Burada asıl önemli olan ise müziğin üreticisi ve tüketicisi olanın da aynı ruhsal ve sosyal duygu dünyasının içerisinde olmasıdır. Özellikle "ergen" kategorisinde değerlendirilen 12-19 yaş arası genç kuşağın bu müziğin hem üretim hem de tüketim aşamasında birincil aktör olduğu görülmektedir. Tüketici ve üretici gençlerin etnik kimlik belirlenimlerine bakıldı̆̆ında "Kürt" oldukları göze 
çarpmaktadır. Böylece rap, aynı zamanda emik ${ }^{1}$ bakışları içerisinde adı geçen Kürt gençlerin "dışlanmışlıklarını"2 maddi ve manevi "damgalanmışlıklarını"3 ifade ettikleri bir müzik tarzı olmaktadır. Rap, aynı zamanda depresif bir ruh coşkunluğu içerisinde topluma, kadere ve insana direnmenin en önemli araçlarından birisi olmaktadır.

Burada özellikle toplumun bir parçası olarak değerlendirilen grup kavramıyla müzik arasındaki kimliksel ilişkiye de değinmek gerekmektedir. İnsanlar müzik grupları etrafında bir birlik oluşturarak dünya görüşlerini oluşturdukları müzik grupları etrafında şekillendirmektedirler. Bazı müzik fanatikleri, kendi müzik tarzına yakın fertler ile daha iyi bir iletişim kurarken, dinledikleri müzik tarzına hitap etmeyen kişiler arasında sosyal anlamda bir iletişim kopukluğu olduğu gözlemlenmektedir. Müziğin oluşturduğu sosyal ağ da tam olarak bu bağlama karşıllk gelmektedir. Arabesk müzik dinleyen bir genç, sosyal çevresi tarafından anlamsız bulunabilir. Aynı şekilde rap müzik seven ve dinleyen birisi, çevresi tarafından rahatlıkla "zevksiz" olarak adlandırmaya açıktır. Öyle ki arabesk müzik sevenler arasında bile belli ayrımlar oluşmakta ve dinleyici kitleleri arasında hayata bakış ve çevreye karşı tutumlar konusunda belirgin farklılıklar oluşmaktadır.

Burada popüler kültür ile popüler müzik arasındaki sosyolojik ilişkilere de değinmek gerekmektedir. Popüler müzik türü günlük yaşamda diğer müzik tarzlarını kapsayacak bir şekle girmiş ve müzik ile yoğun olarak ilgilenmeyen kişiler için müzik kavramı popüler müzik kavramından ibaret olmuştur. Değişik mesleklere sahip olan insanların birçoğunun ortak ağ olan popüler müzik her tür meslekten dinleyicinin ortak bir alanı olmuştur.

\footnotetext{
1 Emik kavramı, topluluğun kendini dışarıdan müdahale-yorumlama olmaksızın ifade etme biçimleri için kullanılmıştır.

2 Buradaki "dışlanmışlık" ifadesi, bir dönem büyükşehirlerde gecekondu bölgelerinde yaşayan gençlerin hayata tutunma mücadelelerine ithafen gündeme getirilmiştir. Dışlanmışlık, kendi yerelliği içerisinde, ana akım gündelik ve kültürel akışa katılamamayı ifade etmektedir. Dolayısıyla burada "dışlanmışlık"ın politik dille herhangi bir ilişkisi yoktur.

${ }^{3}$ Burada damgalanmışlık kavramı, gençlerin hem kendilerini tanımlama biçimlerine hem de sosyal çevrenin onları tanımlama biçimlerine gönderme yapmak için kullanılmıştır. Gençlerin kendilerini tanımlama biçimlerinde "madde kullanımın yarattığı fiziksel rahatsızlıklar", "ruhsal çöküntünün yarattı̆̆ $ı$ depresyon hali", "sürekli isyan hali" gibi betimlemelerle sıralanabilir. Nitekim müziğin içerisinde kullanılan sözlerde de bu durum açıkça görülmektedir. Sosyal çevrenin tanımlamasında ise "ergen" ifadesi ön plana çıkmaktadır. Bu ifade, gençlerin yaptığı bütün davranışları ve tutumları da kendi içerisinde meşrulaştırmaktadır.
} 
Aksu'ya göre (2002: 93), popüler müziklerin yabancılaşma ve yozlaşma anlamındaki olumsuz etkilerinden birisi de, kuralsız esnekliği sonucu, aynı popüler müzik şarkıcısının hem halk müziği, hem sanat müziği hem de arabesk-pop-fantezi türlerini icra etmesinin, bu müziklerin yorum ve icra özelliklerinin giderek tekdüze hale gelmesine neden olmasıdır. Woody (2007: 33), popüler müziğin aslında öğrenmenin anlamının motive olmak olduğunu, popüler müzik süreçlerindeki öğrencilerde daha çok otonomi, yaratıcılık vasıtasıyla bireyselleşmiş öğrenim fırsatları, grup dayanışması ve sosyal getiriler oluştuğunu vurgular. O'na göre müzik öğretmenleri öğrencilerini popüler müziklerle motive edip eğitirken, eğitimsel hedefleri bir yana bırakıp ertelememeli, her etkinlik temeldeki bir öğrenme konusuna hizmet etmelidir.

Popülerin verili bir yapı olmadığını, tarihsel olarak sürekli yeniden inşa edilen bir kategori olduğu açıktır. Kendini sürekli biçimlendirmesi, popüler müziğin sürekli olarak durum değişmelerine bağlı deviniminden, her türlü sınıfsal ya da kültürel ayrımı hem gösterebilmesinden, hem de bu ayrımı ortadan kaldırabilme potansiyeli taşımasından kaynaklanır (Erol, 2002:185). Popüler müzik kendini sürekli olarak piyasanın durumuna göre uyarlar ve piyasanın ruh halini yansıtır. Gündelik, sıradan olarak oluşturulmuş birçok yapı kendini bu müzik tarzı içinde gösterir. Pop müzik olgusu sadece müziğe teknik açıdan yaklaşılan bir alg1 olarak görülmemelidir. Çünkü bu algı içerisinde fertler arasında inşa edilmiş birçok değer yargısı bulunmaktadır.

\section{Araştırmanın Metodolojisi}

Araştırmada, eldeki bağlamı ve bu bağlamla ilişkili durumları, değişkenleri ve değişkenler arasındaki ilişkileri çözümlemeyi amaçlayan tanımlayıcı araştırma modeli kullanılmıştır. Tanımlayıcı araştırmalar genellikle güncel sorunların çözümüne yönelik, pratikteki yararı gözetilerek yapılan uygulamalı araştırmalardır (Ural ve Kılıç, 2011: 19). Böylece bu çalışmanın amacı üniversite öğrencilerinin müziğin toplumsal bağlamıyla ilişkili biçimleri hakkındaki görüşlerini ifade etmelerini ve müzik-toplum veya müzik-sosyal kimlik arasındaki ilişkinin nasıl oluştuğunu belirlemeye yöneliktir.

Araştırmanın evrenini Karabük Üniversitesi öğrencileri oluşturmaktadır. Araştırmanın örneklemi 639 kişi olarak belirlenmiş ve veri toplama aracı olarak araştırmada anket tekniği kullanılmıştır. Anketler, deneklerle yüz yüze görüşülerek uygulanmıştır. Böylece araştırmacıların doğrudan sordukları anket sorularında, insanların tepkilerinin yerinde gözlenmesi amaçlanmıştır. Anket formunda dört grup soru tarzına yer 
verilmiştir. Bunlardan birinci grup cevaplayıcıların demografik özelliklerini, ikinci ve üçüncü grup sorular öğrencilerin bireysel olarak müzikle ilişkili tutumların, dördüncü grup ise öğrencilerin müzik-toplum arasındaki ilişkileri nasıl yorumladıklarını belirlemek amacıyla hazırlanmıştır.

\section{Örneği}

4. Müziğin Kimliklere Yansıma Biçimleri: Karabük Üniversitesi

Araştırmanın bu kısmında sahada elde edilen veriler, Karabük Üniversitesi öğrencilerinin müzikle ilişkili algılarını ve tutumlarını çözümlemeyi amaçlamıştır.

Tablo 1. Örneklem Grubunun Özelliklerinin Demografik Dağılımı

\begin{tabular}{|c|c|c|c|c|c|}
\hline Cinsiyet & $\overline{\text { Sayı }}$ & Yüzde & Siyasi kimlik & Sayı & Yüzde \\
\hline Erkek & 324 & $\% 50,7$ & Boş & 41 & $\% 6,4$ \\
\hline Kadın & 315 & $\% 49,3$ & Milliyetçi & 203 & $\% 31,8$ \\
\hline Toplam & 639 & $\% 100,0$ & Liberal & 54 & $\% 8,4$ \\
\hline Yaşınız & Sayı & Yüzde & $\begin{array}{l}\text { Muhafazakâr/ } \\
\text { Demokrat }\end{array}$ & 67 & $\% 10,5$ \\
\hline Boş & 1 & $\% 0,2$ & Sosyalist/Marksist & 55 & $\% 8,6$ \\
\hline 18 Yaş ve altı & 41 & $\% 6,4$ & Muhafazakâr/İslamcı & 101 & $\% 15,8$ \\
\hline 19-24 Yaş & 570 & $\% 89,2$ & Anarşist & 31 & $\% 4,9$ \\
\hline 25 Yaş + & 27 & $\% 4,2$ & Diğer & 87 & $\% 13,6$ \\
\hline Toplam & 639 & $\% 100,0$ & Toplam & 639 & $\% 100,0$ \\
\hline Yaşanan Yer & Sayı & Yüzde & & & \\
\hline Boş & 2 & $\% 0,3$ & & & \\
\hline Köy/Kasaba & 57 & $\% 8,9$ & & & \\
\hline İlçe & 200 & $\% 31,3$ & & & \\
\hline İl & 372 & $\% 58,2$ & & & \\
\hline Yurtdış1 & 8 & $\% 1,3$ & & & \\
\hline Toplam & 639 & $\% 100,0$ & & & \\
\hline
\end{tabular}

Araştırmada örneklemin demografik niteliklerine bakıldığında; cinsiyet dağılımında kadınların \%49,3, erkeklerin ise $\% 50,7$ oranında olduğu göze çarpmaktadır. Örneklem seçilirken cinsiyet dağılımının birbirine yakın olmasına özellikle dikkat edilmiştir. Yapılan araştırmada katılımcıların yaş durumuna bakıldığında; 19-24 yaş aralığı profilinin \%89,2 gibi yüksek bir oranla ön planda olduğu görülmektedir. Yapılan araştırmaya katılan 
Karabük Üniversitesi öğrencilerinin genel olarak 19 ile 24 yaş aralığına sahip olduğunu ve bununda Türkiye'deki birçok üniversite öğrencisinin yaş aralığına eşit olduğunu anlamlandırmak mümkündür. Katılımclların verdikleri cevaplarda dikkat edilmesi gereken diğer bir nokta ise 19 yaş altı katılımcıların sadece \%6,4'ü temsil etmesidir.

Yaşanilan yer sorusu, ailelerin ikamet ettikleri merkez olarak sorulmuştur. Burada öğrencilerin tatil zamanlarında serbest vakitlerini geçirdikleri yerin niteliği veya yetiştikleri yerin yapısal olarak karşılık geldiği toplumsal alanlara da gönderme yapmaktır. Tabloya bakıldığında katılımcların \%58,2'sinin ailesinin il sınırları içerisinde yaşadıkları görülmektedir. Böylece öğrencilerinin büyük çoğunluğunun "şehirli" olduğunu kabul etmek mümkündür. Buradaki "şehirli" olmak, "modern yaşamın getirilerinden faydalanabilme becerisini" ifade etmektedir. Kırsal alanlarla kıyaslandığında şehir merkezlerinde toplumsal alanlara ulaşmak daha kolay ve rahat olmaktadır. Dolayısıyla şehirde sosyalleşen bir bireyle, kırsalda sosyalleşen birey arasında farklılıklar oluşabilmektedir. Köy-kasaba diyenlerin oranına bakıldığında \%8,9 gibi küçük bir kesim olduğu görülmektedir. Müzik dendiğinde öğrencilerin algılama biçimleri de bu bağlamlara göre değişebilmektedir. "İlçe merkezinde yaşıyoruz" diyenlerin oranı ise $\% 31,3^{\prime}$ tür.

Ankete katılan öğrenciler siyasi kimliklerini genel olarak belirtmişlerdir. Ankete katılan katılımcıların \%6,4'ü, siyasi kimliklerini tanımlamak istememişlerdir. Katılımcıların kendilerini tanımlama biçimlerine bakıldığında en yüksek oran \%31,8 ile milliyetçiyim diyenlerin olduğu görülmektedir. Kendisini muhafazakâr/İslamcı olarak tanımlayanların oranı ise \%15, $8^{\prime}$ dir. Muhafazakâr/demokrat olarak tanımlayanların oranı ise $\% 10,5^{\prime}$ tir. Burada kuşkusuz bir bütün olarak bakıldığında kendisini muhafazakâr ve milliyetçi olarak tanımlayanların yüksek olduğu görülmektedir. Öğrencilere siyasi olarak kendilerini nasıl tanımladıklarının sorulması, müziğin algılanma biçimlerinde bu kimliklerin önemli bir belirleyici olduğunun düşünülmesidir. 
Tablo 2. Müziğe Olan İlginin Değerlendirilme Biçimi

\begin{tabular}{||l|c|c||}
\hline Seçenekler & Say1 & Yüzde \\
\hline Çok iyi & 229 & $\% 35,8$ \\
\hline İi & 238 & $\% 37,2$ \\
\hline Orta & 132 & $\% 20,7$ \\
\hline Zayıf & 21 & $\% 3,3$ \\
\hline Hiç & 19 & $\% 3,0$ \\
\hline Toplam & $\mathbf{6 3 9}$ & $\mathbf{1 0 0 , 0}$ \\
\hline
\end{tabular}

Tüm sanat dalları içinde, insan ruhu üzerinde en derin etkiyi bırakan sanatın müzik sanatı olduğu kabul edilmektedir. Toplumla etkileşip bütünleşen sanatların başında müzik yer alır. Müziğin, insandan insana uzanan evrensel bir dil olması, dili ve dini ayrı bir yer ve farklı bir ayrıcalık vermiştir (Öz, 2001: 102). İnsanlar müzikle ister istemez iç içe yaşamaktadırlar. Müziğin etkili bir sanat dalı olması, onun insanların duygu ve düşüncelerini aktarma konusunda önemli bir rol oynadığının da göstergesidir. Bu bağlamdan hareketle gençlere yöneltilen sorulardan birisi müziğe ilgi derecelerinin nasıl ifade ettikleri olmuştur. Tabloya bakıldığında katılımcıların müziğe olan ilgilerinin $\% 35,8$ ile çok iyi ve $\% 37,2$ ile de iyi olarak değerlendirildiği görülmektedir. Müziğe ilgilerinin orta olduğunu söyleyenlerin oranı ise \%20,7 olarak sonuçlara yansımıştır. Müziğe ilgilerinin zayıf veya hiç olduğunu ifade edenlerin oranı ise katılımcıların toplamda \%6,3'üne denk düşmektedir. Tablodan anlaşılacağı üzere katılımcılar, müziğe karşı doğrudan bir ilgilerinin olduğunu ifade etmişlerdir.

Burada dikkate alınması gereken temel bağlam ise; şu veya bu sebepten müziğe olan ilginin çoğunlukla ortanın üstünde olmasıdır. Cinsiyete göre müziğe ilgi arasında çapraz ilişki kurulduğunda, her iki demografik değişken için de müzik, ilginin "çok iyi" ve "iyi" düzeyde olduğu alanlardan birisi olarak göze çarpmaktadır. Çalışmayı temellendiren en belirgin varsayımlarından birisi olan "katılımcıların büyük bir çoğunluğu müziğe karşı ilgi geliştirmektedir" ifadesini doğrulamaktadır. Böylece seçilen kitlenin, araştırmanın ana başlığı olan "müzik-kimlik" ilişkiselliğine uygun olduğu görülmektedir. 
Tablo 3. Müziğin Kültür Birikimini Yansıttığına İnanma Durumu

\begin{tabular}{||l|c|c|}
\hline Seçenekler & Sayı & Yüzde \\
\hline Evet & 447 & $\% 70,0$ \\
\hline Hayır & 85 & $\% 13,3$ \\
\hline Kararsızım & 107 & $\% 16,7$ \\
\hline Total & $\mathbf{6 3 9}$ & $\mathbf{\% 1 0 0 , 0}$ \\
\hline
\end{tabular}

Müziğin kültür birikimini yansıtıp-yansıtmadığ sorulduğunda katılımcıların \%70'i, müziğin kültür birikimini yansıttığını düşündüklerini

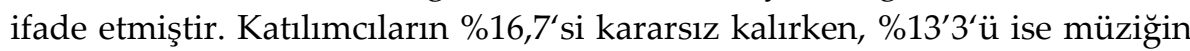
kültür birikimini yansıtmadığını düşünmüştür. Müziğin kültür birikimini yansıtıp-yansıtmadığı sorusunun siyasi değişkene göre çapraz ilişkisi sorgulandığında ise; kendisini milliyetçi, muhafazakâr ve sosyal demokrat olarak tanımlayanların müziğin kültür birikimini yansıttığına inandıkları görülmüştür. Aynı sonuçlar, cinsiyet değişkenine göre çapraz sorgulandığında ise her iki cinsinde müziğin kültürel birikimle olan ilişkisini onayladıkları görülmüştür.

Müzik, kültür ile doğrudan ilişkili bir sanat dalıdır. Çünkü "müzik, bir kültürün sembolik anlatımı veya bir gurun yaşam biçimi olması nedeniyle fonksiyonel olarak bireyi grup içinde uyumlu, katılımcı ve düzenli davranış oluşturmada yönlendirici" (Cengiz, 2011: 364) olabilmektedir. Burada müziği kültürel göstergeye dönüştüren en belirgin noktalardan birisi de kuşaklararası bağlantıyı sağlıyor olmasıdır. Halk müzikleri veya ulusal marşlar böyle örneklerdir. Kültürel bir öğe olarak müzik karşısında grup üyeleri aynı hisleri ve heyecanları duyarlar. Müzik aracılığıyla, kültürel bellek, aynı derecede canlanır ve bireyleri bir arada tutan bir sisteme evrilir. Böylece müziğin sosyolojik bir temaya kendiliğinden dönüştüğü görülür. Müzik Bilimi, kendi içerisinde teknik bir takım anlama sahip olsa da, içinde bulunduğu toplumun maddi manevi değerlerinden Bağımsız düşünülemez. Aksu'ya göre (2002: 155) müzik, bir toplumun yarattığı kültürün, en temel yansımalarından birisi olurken, toplumun geçirdiği değişikliklerden etkilenenlerin de başında gelmektedir. 
Tablo 4. Dinlenilen Müzik Tarzı Dağılımı

\begin{tabular}{||l|l|l||}
\hline Seçenekler & Sayı & Yüzde \\
\hline Türk Halk Müziği & 116 & $\% 18,1$ \\
\hline Türk Sanat Müziği & 75 & $\% 11,7$ \\
\hline Tasavvuf Müziği & 52 & $\% 8,1$ \\
\hline Enstrümantal Müzik & 37 & $\% 5,8$ \\
\hline Alternatif Müzik & 31 & $\% 4,9$ \\
\hline Pop Müzik & 143 & $\% 22,4$ \\
\hline Arabesk Müzik & 38 & $\% 6$ \\
\hline Rock Müzik & 43 & $\% 6,8$ \\
\hline Hip Hop/ Rap Müzik & 36 & $\% 5,6$ \\
\hline Diğer & 68 & $\% 10,6$ \\
\hline Toplam & $\mathbf{6 3 9}$ & $\mathbf{\% 1 0 0 , 0}$ \\
\hline
\end{tabular}

Müzik sanatını diğer sanat dallarından ayıran en önemli özelliklerden biri de, insanların çok büyük bir emek harcamadan bu sanat dalından yararlanabilmeleridir. Kolay ulaşılabilir bir alan olması bakımından müzik topluluk üyesi birçok kişi tarafından yoğun bir şekilde tercih edilmektedir. Katılımcıların müzik dinleme tercihlerine baktığımızda, dikkat çeken önemli ayrıntılardan biri pop müziğin \%22,4 ile diğer müzik tarzlarına göre ön plana çıkmasıdır. Pop müzik tarzının bu derece yüksek oranda dinlenilmesi popüler kültürün insanlara aşıladığ 1 değerler ile açıklanabilir. Nacakçı'ya göre (2005: 201) bu oluşum; popüler bir batılılaşma hareketidir. Batı'dan gelen lüks eşyalar, modern makineler, açılan yeni iş sahaları; Batı'yı örnek alan yapılar, yollar, ışıklı panolar derken toplum üyeleri, büyük kentlerin öncülüğünde, Batı'yı tanımaya başlarlar. Batı'ya özenen, Batı'yı kendine örnek alan kent yaşamı, ülke üzerinde ağırlığını arttırdıkça Batı kültürü ile giderek daha çok hissedilmeye başlamıştır.

Popüler kültür olgusu tüketim toplumunun ayrılmaz bir parçasıdır. Tüketim toplumu asıl dönüşümü Modernizmin getirmiş olduğu değerlerin yaygın hale gelmesiyle yaşamıştır. Burada popüler müzik olgusundan kastedilen, piyasa müziği olarak adlandırılan, toplum tarafından hızlıca tüketilen ama sanatsal değeri az olan bir gerçekliğe işaret eder. Çünkü "makinenin müdahalesi, kültürün mekanikleştirilmesi ve kültürün bilinç endüstrisi tarafindan medyalaştırılması" (Jameson, 1994: 108) onun hızlı tüketilmesinin de ana nedenlerinden birisi olarak göze çarpmaktadır. Örneğin 1990'l1 yıllarda popüler olan parçaların şimdi çok sık dinlenmiyor olmaması bu gerçekliğin bir parçasıdır. Popüler müzik küreselleşmenin getirdiği bir 
olgudur ve gün geçtikçe karmaşık bir hal almaktadır. Aksu'ya göre (2002: 96) popüler müziklerin yabancılaşma ve yozlaşma anlamındaki olumsuz etkilerinden biri de, kuralsız esnekliği sonucu, aynı popüler müzik şarkıcısının hem halk müziği, hem sanat müziği hem de arabesk-pop-fantezi türlerini söylemesinin, bu müziklerin yorum ve icra özelliklerinin giderek tekdüze/standart hale gelmesine neden olmasıdır.

Dinlenilen müzik tarzlarının sıralamasına bakıldığında \%18,1 ile Türk Halk Müziği'nin ikinci sırada olduğu görülmektedir. Orta Asya Türk geleneğinin bir uzantısı olarak günümüzde kadar, Anadolu kültürünün ortak havzasında evrimleşerek gelişen Türk Halk Müziği, bu coğrafyada yaşamış tüm halkların müzik kültürlerinin de bir sentezidir (Öğel, 1998: 9). Tüketim toplumunda Türk Halk Müziğinin diğer müzik tarzlarından daha fazla tercih edilmesi, katılımcıların tüketim kültürünün yaygın olması karşısında bile kendi "yerel değerlerine" gösterdikleri önemin bir yansıması olarak değerlendirilebilir. Türk Halk Müziği geleneksel değerlerin bir parçası olduğu için yaşanılan toplumun ayrıntılı folklorik temalarını serimler. Küreselleşmenin toplumları tek tipleştirdiği bir ortamda topluluk üyelerinin halk müziği üzerinden kendi değerlerine sahip çıkması bu anlamda dikkate değer bulunmuştur.

Dinlenilen müzik tarzlarına bakıldığında tabloda \%11,7 ile Türk Sanat Müziği'nin dikkat çektiği görülmektedir. Türk Sanat Müziği köken açısından çeşitli kültürlerin harmanlandığı ve daha çok Osmanlı geleneğinin izlerini taşıyan bir müzik tarzı olması itibariyle, kültür birikimi açısından zengin bir kaynağa sahiptir. Türk sanat müziği, diğer türlerden birkaç farklı yönden ayrılır. Halk müziği gibi yöresel değildir ve pop müzik gibi sıradan yan yana getirilmiş sözleri yoktur. Arabesk gibi insanı isyana sürüklemez; aksine klasik müzik gibi dinlendirici etkisi vardır. Eski klasik eserler özellikle divan şiirlerinden bestelenmiş olup derin anlamlar içermektedir. Yahya Kemal Beyatlı'nın da dediği gibi "çok insan anlayamaz eski musikimizden ve ondan anlamayan bir şey anlamaz bizden". Ayrıca kültürel belleğin öğrenilmesinde çok güçlü bir kaynak olduğunu da iddia etmek mümkündür. Türk Sanat Müziği ayn zamanda her dönem "güzelliğin, anlamin ve sevginin sembolü" olarak göze çarpmıştır.

Tasavvuf müziği dinleyenlerin oranının ise $\% 8,1$ olduğu görülmektedir. Kuşkusuz burada tasavvuf müziğinden kastedilen içerik, "ilahi" veya ilahi biçimde düzenlenmiş olan biçimlerdir. Anketler uygulanırken katılımcilara, tasavvuf müziğinden özellikle ilahileri anlamak gerektiği hatırlatılmıştır. Burada bu müzik türüyle ilişkili olarak günümüze dair iki önemli tespit yapmak yerinde olacaktır. Bunlardan ilki klasik ilahi biçimlerinin devam ettirildiği görülmekle birlikte bu biçimlerin özellikle 
Ramazan Ayı süresince ön plana çıktığının dikkat çekmesidir. Ayrıca kandiller ve özel dini günlerde de bu türün sıkça kullanılması söz konusudur. Kitle iletişim araçlarında ön plana çıkan bu tür, kuşkusuz dinleyici kitlesi açısından gençleri de yoğun bir şekilde etkilemektedir. Bunlardan ikincisi ise ilahilerin popüler müzik içerisinde kitle iletişim araçlarının sunduğu imkânlarla da gündelik hayatın bir kültürü haline gelmesidir. Kuşkusuz bu "muhafazakâr müzik" olarak adlandırılan bir sürecin son aşaması olarak değerlendirilebilir. Aksiyon Dergisi'nin 2007 yılında hazırladığı dosyada bu sürecin hikâyesini bulmak mümkündür. 80'li yıllarda zikir albümleri elden ele kayıt edilerek dolaştırılırken, 90'lı yılların başına gelindiğinde radyo tiyatroları muhafazakâr kesimde yaygınlaşmaya başladı. Türkiye Gazetesi'nin dağıttığı sesli tiyatro kasetlerinin büyük tirajlara ulaştığı dönemlerde klasik üslubu barındıran ritim ve nefesin dışına çıkılmaya da başlandı. 1992'de yayın hayatına başlayan özel radyoların varlığı, gelenekselden kopmayan; ancak günün popüler kültürünü içinde barındıran eserle ihtiyaç olduğunu ortaya koydu. Aksiyon'un dosyasına göre "Yeşil Pop" adı verilen çağ da bu dönemde başladı. 2000'li yıllardan sonra ise değişen siyasi iktidarla birlikte yükselen muhafazakâr orta sınıf, İslami müziğin de değişiminin habercisi olmuştur. Sami Yusuf örneği ${ }^{4}$ bu bağlamda önemlidir. Böylece popüler kültürün doğrultusunda hareket eden bir muhafazakâr müzik karşımıza çıkmıştır. ${ }^{5}$

Dinlenilen müzik türlerine bakıldığında arabesk müziğin de \%6 oranıyla dikkat çektiği görülmektedir. Batı müziğinde rondoyu ${ }^{6}$ anımsatan süsleme türü olarak bilinen "arabesk" kelime anlamı olarak birbirleriyle kesişen geometrik ve çizgisel öğelerden oluşan bir bezeme türü olarak tanımlanmaktadır. Arabesk, Türkiye'de sosyolojik olarak bir topluluğun ruh haline referans gösterilen müzik türüdür. Çünkü arabesk toplumsal yaşam biçiminizin aksaklıklarını anlatmak için kullanılır olmuştur (Bkz. Güngör, 1993). Arabesk müzik içinde barındırdığ 1 "gerçeklik" itibariyle erkeklerin

\footnotetext{
${ }^{4} 26$ yaşındaki Azeri kökenli sanatçı, İngiltere Kraliyet Müzik Akademisi'nde aldığ eğitimden hareketle, hâkim olduğu Batı soundunu kullanarak Arapça, İngilizce hatta Türkçe ilahiler ve ezgiler okuyor. 2004 yılında ilk albümü Al-Mu'allim'i yayımlayan Sami Yusuf, bir yıl sonra kendisini dünya çapında bir üne taşıyan My Ummah'ı sundu. Türkiye'de de çok büyük ilgi gören Yusuf için 'İslami popstar' deniliyor.

${ }^{5}$ Dosya'nın "Muhafazakar Müziği Kullanma Kılavuzu” başlıklı içeriği için bkz. http://www.aksiyon.com.tr/dosyalar/muhafazakar-muzigi-kullanmakilavuzu 517155 (Yayın Tarihi:24 Eylül 2007), Erişim Tarihi: 20.01.2015.

6 Çizginin sürekli hareketiyle birbirinin içine geçen biçimlerden oluşan yüzey bezemesine verilen ad.
} 
tercihine daha açık bir müzik tarzıdır. Çünkü arabesk müzik hayata karşı isyanın, kederin, üzüntünün sembolü olmuştur ve içerdiği isyan-şiddet temalarıyla erkeğin hayat karşısındaki mücadelesine yanıt veren bir müzik tarzı olarak kabul edilmiştir. Arabesk müziğin serüveni, Türkiye'nin 1950'li yıllardan sonra sanayileşme süreciyle başlar. Göçlerle birlikte İstanbul ve Ankara'ya kırsal alanlardan gelen insanların, kentte tutunma hikâyeleri başarısızlıklarla karşılaştığında arabesk müzik denilen tarzın ortaya çıkışı da gözlenmiştir. Arabesk müzik, aynı zamanda bir topluluğun kültürel pratiklerini ifade eden birkaç müzik tarzından birisidir. Arabesk, 1970'lerden 1990'lı yıllara kadar Türkiye'de hem müzik kültürü hem de bir topluluğun kimliği olarak sıklıkla sosyolojik araştırmalarda önemli bir araştırma konusu olmuştur.7 Ayrıca arabeskin içindeki temalar nedeniyle, "suç profilini sergileyen bireyler" için de arabesk, sıklıkla dinlenen türlerden birisidir. Gündelik hayat içerisinde ortaya çıkan suçluların (Katil, cani, tecavüzcü vs), "ağır damar" parçalarını dinledikleri ve bu parçalarla hayatlarına anlam vermeye çalıştıklarını ileri sürmek mümkündür.

Rap müzik dinleyenlere bakıldığında tabloda \%5,6 oranıla dikkat çekmiştir. Diğer müzik türleriyle kıyaslandığında oranı gençler arasında düşük olmakla birlikte, rap dinleyicilerinin arabesk müzik gibi fanatik olması bizce özellikle yorumlanması gereken noktalardan birisidir. Hiphop'un bir biçimi olarak rap, özellikle popüler medya araçlarında gündemde olması ve gençlerin dünyayı ifade etme biçimlerinde kolay bir seçenek olması bakımından tercih edilmiştir. Rap'in gettolara giden kökleri ve İngilizce 'de "ağır eleştiri" anlamına gelen karşılığı, kuşkusuz gençlerin müzik tarzını hızlı benimsemelerinde bizce etkili olmuştur. Türkiye örneğine bakıldığında günümüzde bir alt kültürden ana akım popüler kültüre dönüş hikâyesinde medya araçlarının merkeziliğinin altını da çizmek gerekir. Ceza'nın Sezen Aksu ve Candan Erçetin gibi pop müziğin önemli isimleriyle düet yapması, "Fark Var" şarkısının popüler bir televizyon dizisi olan "Adanalı"nın müziği ya da 2009 yerel seçimlerde bazı partiler tarafından seçim müziği olarak kullanılmak istenmesi, Sagopa'nın Cem Yılmaz'ın G.O.R.A. filmine "Al 1'de Burdan Yak" isimli şarkıyı yapması örneklerinde olduğu gibi pek çok alanında karşımıza çıkan rap müzik, böylece popüler kültürün önemli ayaklarından birisi haline gelmiştir (Lüküslü, 2011: 202).

\footnotetext{
7 Bu konuda yapılmış farklı çalışmalar için bkz. Nazife Güngör, Arabesk, Bilgi Yayınevi, 1993; Meral Özbek, Popüler Kültür ve Orhan Gencebay Arabeski, İletişim Yayınları, 2012; Martin Stokes, Türkiye'de Arabesk Olayı, çev: Hale Eryılmaz, İletişim Yayınları, 2010.
} 
Burada diğer seçeneğini işaretleyenler arasında "belirtiniz" ifadesine ek olarak yazılanlar arasında "taverna, klasik, etnik ve yerel müzik" çeşitlerinin olduğu not alınmıştır.

Cinsiyet ile tercih edilen müzik türleri arasındaki çapraz ilişki sorgulandığında kadınların pop müziği daha fazla tercih ettikleri görülmüştür $(\% 70,7)$. Erkeklerde ise bu oran kadınlara göre oldukça düşüktür (\%29,3). Bu oranın kadınlarda yüksekliği, kadının tüketim kültürü içerisinde daha yoğun kullanılan bir tema oluşuyla ilişkilendirilebilir. Pop Müzik yapısı itibariyle tüketim kültürünün sembolü konumundadır. Diğer müzik türlerinden ayrılan en önemli özelliği ise popüler kültür konumunda olması ve modasının zamanla geçmesidir. Sanat Müziği dinleyenlerin oranı erkeklerde \%62,0, kadınlarda ise \%38,0'dır. Erkeklerde bu oranın kadınlardan daha yüksek olması, erkeklerin her ne kadar arabesk müzik dinlemeye yatkın olmalarına rağmen, sanat müziği gibi "derin" ve "ince"8 anlamı barındıran bir müzik tarzını da aynı zamanda dinlediklerini gösterir. Diğer müzik tarzlarına bakıldığında ise oranların birbirlerine yakın oldukları görülmektedir.

Tablo 5. Takip Edilen Konserler ve Festivallerin Olup Olmadığ Durumu

\begin{tabular}{||l|l|l||}
\hline Seçenekler & Say1 & Yüzde \\
\hline Yok & 239 & $\% 37,4$ \\
\hline Ulusal festivaller-konserler & 78 & $\% 12,2$ \\
\hline Yerel Festivaller-konserler & 232 & $\% 36,4$ \\
\hline Uluslararası festivaller-konserler & 49 & $\% 7,8$ \\
\hline Diğer & 41 & $\% 6,2$ \\
\hline Toplam & $\mathbf{6 3 9}$ & $\mathbf{\% 1 0 0 , 0}$ \\
\hline
\end{tabular}

Müzik ile kimlik arasında kurulan ilişki biçimlerinde dikkat çeken önemli noktalardan birisi de müziğin takip edilme biçimleridir. Bu takip edilme biçimlerinde, kuşkusuz farklı demografik özelliklerdeki bireylerin aynı amaç için bir araya gelmesi ve kolektif bir bilinç oluşturmasına gönderme yapılmaktadır. Tabloya bakıldığında herhangi bir konser ya da festival takip etmediğini söyleyenlerin oranı $\% 37,4$ 'tür. Yerel festivalleri ve konserleri takip ettiğini söyleyenlerin oranı ise $\% 36,4^{\prime}$ tür. Ulusal festivaller

${ }^{8}$ Burada bahsi geçen incelik ve derinlik, Türk Sanat müziğinin yoğunluklu olarak edebi sanatla yakından ilişkili olmasını ifade etmek için kullanılmıştır. Müziğin ağır ritmi ve klasik Batı müziğine yakın tonları da bu ifadelerin kullanılması için yeter kabul edilmiştir. 
ve uluslararası festivalleri takip edenlerin de katılımcılar arasında olduğu görülmektedir.

Festival ve konserlerin dikkate değer bulunmasının temel nedeni, müzik etrafında oluşan sosyal ağların tanımlanmasında önemli birer araç olmasıdır. Ortak bir amaç için bir araya gelen bireyler, bir süre sonra müzik dinlemekten ziyade kendi aralarındaki sosyal etkileşimler üzerinden paylaşım yapmaktadırlar. "Kız-erkek ilişkileri", "bireyler arasında kurulan sohbet bağları", "ülkenin gündemine dair sorunların konuşulması" başta olmak üzere bireylerin farklı biçimlerde vitrin sunumları yaptıkları görülmektedir. Burada vitrinden kasıt, bireylerin toplandıkları alanda birbirlerine karşı kullandıkları kimlik argümanlarıdır. ${ }^{9} \mathrm{Bu}$ argümanlar, aynı zamanda kimliklerin dışa vurumlarıdır. Müziğin burada dikkat çeken yönü ise kimliklerin farklı bağlamlarda dışa vurumları için oluşturduğu fonksiyonel birlikteliktir. Böylece müziğin, yarattığı toplumsal alanlar üzerinden sosyolojik derinliğine ulaşmak mümkün olmuştur. Tıpkı "yemek" etrafında yapılan sosyal paylaşımların sosyolojik değeri gibi, "müzik" etrafında yapılan sosyal paylaşımların da bu derece önemli olduğu görülmektedir. Müziğin üstlendiği fonksiyonlarla toplumsal ve kültürel yapı varlığını devam ettirmektedir.

Tablo 6. Bu Tür Etkinliklerin Müzik Dinlemeye Katkısı Olduğunu Düşünme

\begin{tabular}{||l|l|l|}
\hline Seçenekler & Sayı & Yüzde \\
\hline Evet & 423 & $\% 65,9$ \\
\hline Hayır & 66 & $\% 10,7$ \\
\hline Kararsızım & 97 & $\% 15,0$ \\
\hline Fikrim Yok & 53 & $\% 8,4$ \\
\hline Toplam & $\mathbf{6 3 9}$ & $\mathbf{\% 1 0 0 , 0}$ \\
\hline
\end{tabular}

Yukarıdaki soruya bağlantılı olarak "bu tür konser ve festivallerin müzik dinlemeye katkısı olup olmadığının" düşünülme durumu sorgulanmıştır. Tabloya bakıldığında katılımciların $\% 65,9^{\prime} u$ bu tür etkinliklerin müzik dinlemeye katkısı olduğunu düşünmüş; \%15’i bu tür etkinliklerin olumlu katkısı olduğu konusunda kararsız kalmıştır. \%10,7 ise bu tür etkinliklerin

\footnotetext{
${ }^{9}$ Erving Goffman'ın "vitrin" kavramı; bireylerin sosyal hayatın içerisinde kendilerine oluşturdukları dışsal görüntülere gönderme yapmakta ve bireylerin vitrinler üzerinden kimliklerini sunduklarına işaret etmektedir (Daha ayrıntılı bilgi için Bkz. Goffman, 2012).
} 
olumlu katkısının olmadığını düşünmüştür. Sonuçlar bir bütün olarak değerlendirildiğinde, bu tür etkinliklere katılım olmasa da deneklerin büyük bir çoğunluğunun konser ve festivalleri değerli bulduğu görülmektedir. Kuşkusuz bu tür etkinliklerin bireylerin bir araya getirme açısından fonksiyonelliği düşünüldüğünde, katılımcıların bu değerlendirme biçimlerinin kaçınılmaz olduğu anlaşılmaktadır.

Tablo 8. Konserlere ya da Festivallere Gitme Sıklığ

\begin{tabular}{||l|l|l||}
\hline Seçenekler & Sayı & Yüzde \\
\hline Sık sık & 83 & $\% 13,0$ \\
\hline Ara sıra & 461 & $\% 72,1$ \\
\hline Hiç gitmem & 95 & $\% 14,9$ \\
\hline Toplam & $\mathbf{6 3 9}$ & $\mathbf{\% 1 0 0 , 0}$ \\
\hline
\end{tabular}

Karabük Üniversitesi öğrencilerinin konser ve festivallere gitme sıklığı sorgulandığında katılımcıların \%14,9'u hiç gitmediklerini belirtmişlerdir. "Sik sık giderim" diyenlerin oranı ise \%13'tür. "Ara stra giderim" diyenlerin oranının ise $\% 72,2$ ile en yüksek oran olduğu görülmektedir. Demografik değişkenler içerisinde cinsiyet ile konserlere gitme sıklığı arasında çapraz ilişki sorgulandığında; "konserlere hiç gitmem" diyenlerin büyük bir çoğunluğunun kadınlar olduğu görülürken, "sık sık giderim" diyenlerin büyük çoğunluğunu da erkekler oluşturmaktadır.

Tablo 9. Müzik Dinlemek ve Eğlenmek İçin Gidilen Mekanlar/Yerler

\begin{tabular}{||l|l|l||}
\hline Seçenekler & Sayı & Yüzde \\
\hline Bar, disko & 85 & $\% 13,3$ \\
\hline Kafe & 166 & $\% 26,0$ \\
\hline Konser & 179 & $\% 28,2$ \\
\hline Diğer & 209 & $\% 32,5$ \\
\hline Toplam & $\mathbf{6 3 9}$ & $\mathbf{\% 1 0 0 , 0}$ \\
\hline
\end{tabular}

Katılımcılara yöneltilen bir başka soru ise müzik dinlemek ve eğlenmek için mekân tercihinin ne olduğu olmuştur. Bu soruda kuşkusuz üniversite öğrencilerinin sosyalleşme biçimleri de sorgulanmak istemiş ve bunun müzikle ilişkili tarafları betimlenmek istenmiştir. Tabloya bakıldığında katılımcların \%32,5'i diğer seçeneğini işaretleyerek herhangi bir belirleyici cevap vermemiştir. Diğer oranlara bakıldığında katılımcıların 
$\% 28,2$ 'si müzik dinlemek ve eğlenmek için konserleri tercih ettiklerini belirtmişlerdir. Kafe seçeneğini işaretleyenlerin oranının ise \%26,0 olduğu görülmektedir. Bar ve disko yanıtını verenler ise katılımcların sadece \%13,3'ünü oluşturmaktadır.

Burada Karabük Üniversitesi'nin sosyal çevresi hakkında bir betimleme yapmak, sonuçların anlaşılması açısından yerinde olacaktır. Üniversite henüz gelişme aşamasında olan bir şehirde olduğundan dolayı konser ve festival etkinlikleri sınırlı sayıda gerçekleşmektedir. Konserlerin sınırlı sayıda olması ise etkinliklere katılımın yüksek olmasına kaynaklık etmektedir. Konserlerin halka açık olması, üniversite öğrencileri ile Karabük halkı arasında yeni bir etkileşim alanı oluşturmakta ve böylece müzik etrafında ortaya çıkan yeni bir sosyolojik alanının varlığına gönderme yapmaktadır. ${ }^{10}$ Konserler dışında bir alan olarak kafe ve kafeler kültürü dikkat çekmektedir. Öğrenci sayısının yüksek olması, özellikle üniversiteye yakın mahallelerde kafe kültürünün gelişmesine imkân sağlamıştır. Öğrenciler, böylece serbest zaman etkinliklerinin büyük bir kısmını üniversite mahallesinde kafelerde geçirmektedir. Kafelerde geçerli olan etkinlikler ise yemek yemek, oyun oynamak, sohbet için toplanmak, maç izlemek ve bütün bunların yanında canlı müzik ya da bilgisayardan müzik dinlemektir. Kuşkusuz ilerleyen dönemlerde, üniversitenin gelişimine paralel olarak kafe kültürünün ve bununla birlikte müzik olgusunun daha farklı boyutlara taşınacağı da aşikârdır.

Burada ayrıca Karabük genelinde öğrencilerin müzik dinleme açısından diğer mekân seçeneklerini sıralamak mümkündür. Karabük'te eğlence mekânlarından en bilineni ve büyük olanı Büyük Kulüp'tür. Hafta sonları canlı müziğin olduğu mekânda, dinleyicilerden müzik ücreti alınmıyor. Karabük'e bağlı Safranbolu ilçesinde yıllardır yerli yabancı birçok turisti konuk eden konakların bulunması, burayı daha çok ilgi çekici bir hale getirmektedir. Burada dikkat çeken nokta ise konakların birçoğunun misafirlerini müzik eşlinde karşılamalarıdır. Kültürel faaliyetlerin en fazla yoğunlaştığı mekânlardan birisi Taşev Sanat ve Şarapevi'dir. Burada hafta sonları canlı müzik ile birlikte öğrencilerin de zaman zaman katıldığı etkinlikleri yapılmaktadır. Ayrıca Karabük'ün çeşitli yerlerinde bulunan birahaneler de diğer mekanlara göre fiyat konusunda daha uygun olduğundan öğrenciler tarafından müzik için tercih edilen mekanlardan bir diğeridir. Kimsenin birbirini tanımadan sosyal etkileşim kurduğu bu

${ }^{10}$ Karabük Üniversitesi ile Karabük halkı arasında ortaya çıkan karşılıklı etkileşimler için şu araştırmaya bakılabilir: Adem Sağır ve Ülkü H. İnci, "Karabük'te Üniversite Algısı: Karabük Üniversitesi Örneği", İTOBİAD, Cilt.2, Sayı:2, 2013. 
mekanlar, öğrenciler için farklı bir sosyalleşme alanı olarak karşımıza çıkmaktadır.

Tablo 10. Bazı Müzik Türlerinin Günah Olduğunu Düşünme

\begin{tabular}{||l|l|l|}
\hline Seçenekler & Sayı & Yüzde \\
\hline Evet & 230 & $\% 36,0$ \\
\hline Hayır & 262 & $\% 41,0$ \\
\hline Kararsızım & 98 & $\% 15,3$ \\
\hline Fikrim yok & 49 & $\% 7,7$ \\
\hline Toplam & $\mathbf{6 3 9}$ & $\mathbf{\% 1 0 0 , 0}$ \\
\hline
\end{tabular}

Araştırma sırasında öğrencilere yöneltilen sorulardan biri de geleneksel kalıp yargılarla ilişkili düşünülen müzik-günah dikotomisidir. Bu bağlamdan hareketle "bazı müzik türlerinin günah olduğunu düşünüyor musunuz?" sorusuna, katılımcıların \%36,0's1 evet yanıtını vermişlerdir. "Hayır", yanitını verenlerin yanitı ise katılımciların \%41,0'ini oluşturmaktadır. Genel olarak baktığımızda ise oranlar arasında ciddi bir fark olmadığını iddia etmek mümkündür. Ancak bazı müzik türlerinin günah olduğunu düşünenlerin oranı küçümsenmeyecek bir değerdedir. Burada "hangi tür müziklerin günah olduğu" sorusu akla gelebilir. Çalışma süresince özellikle araştırmacının doğrudan uygulamasını yaptığı anketler sırasında merak edilen önemli noktalardan birisi bu soruya verilen "evet" cevabının detayları olmuştur. Katılımcilardan 6 tanesi, "arabesk müzik" üzerinde duran oldukça fazladır. Özellikle müziğin sözlerinin "Kader" ve "Tanrıya" isyan şeklinde kendini kurduğunu belirten katılımcılar, bu bağlamda arabesk müziğe kendini fazla kaptırmanın insanı "dinden bile çıkartabileceğ i" iddiasını ileri sürmüştür. Arabesk ile aynı sonucu paylaşan diğer müzik türü ise katılımcılardan 3'ünün özellikle belirttiği notla "rap" müzik türü olmuştur. Rap müziğin günah olduğu düşüncesinde "kader" ve "Tanrıya" isyan içerdiğine dair algıya, bu kez "argo" kullanımı da eşlik etmiş̧ir. Argonun rap müzikte kullanımı, müziğin toplumu yozlaştırıcı bir etkisi olarak değerlendirilmekte ve ahlaki tartışmalara konu edilmektedir. Daha farklı bir bağlamda ise katılımclardan 2'sinin "alkolün kullanıldığ türlü mekânda hangi müzik çalarsa çalsın günahtır" önermesini ileri sürdükleri not alınmıştır. $\mathrm{Bu}$ noktada müziğin araçsallığının hangi niyetle kullanıldığının dile getirilmesi söz konusudur. 
Araştırmada "müzik-günah" ilişkisiyle katılımcıların kendilerini siyasi olarak tanımladıkları değişkenler arasında çapraz ilişki sorgulandığında ortaya çıkan sonuçlarla ilgili şu betimlemeleri yapmak mümkündür. Sonuçlara göre kendisini "muhafazakâr ve İslamcı" olarak tanımlayanların bazı müziklerin günah olduğu fikrinde yüksek oranda olduğu görülmüştür. Cinsiyet açısından bakıldığında ise erkeklerin bu konuda daha net oldukları ve kadınlarla kıyaslandıklarında bazı müzik türlerinin günah olduğunu daha yüksek oranda düşündükleri görülmüştür.

Tablo 11. Müziğin Milli Duyguları Harekete Geçirdiğine İnanma

\begin{tabular}{||l|l|l|}
\hline Seçenekler & Sayı & Yüzde \\
\hline Evet & 430 & $\% 67,3$ \\
\hline Hayır & 93 & $\% 14,6$ \\
\hline Kararsızım & 76 & $\% 11,8$ \\
\hline Fikrim yok & 40 & $\% 6,3$ \\
\hline Toplam & $\mathbf{6 3 9}$ & $\mathbf{\% 1 0 0 , 0}$ \\
\hline
\end{tabular}

Katılımcıların \%67,3'ü müziğin milli duyguları harekete geçirdiğine inanırken, \%14,6'sı müziğin milli duyguları harekete geçirmesi konusunda etkisiz olduğuna inanmıştır. Kararsızların oranı ise müziğin milli duyguları harekete geçirmediğine inanmayanlarla yakın seviyededir. Müzik sadece teknik ve sanatsal anlamda değerlendirilebilecek bir olgu değildir. Müzik içinde barındırdığı anlatım diliyle, insanlara belirli ideolojiler kazandırmasında önemli fonksiyonlar üstlenmektedir. Örneğin, Osmanlı Dönemi'nde savaş zamanında Mehteran; savaşa çıkan askerleri motive etmesi bakımından önemli bir uygulamaydı. Milli marşlar karşısında toplumun bütün üyelerinin aldığı tavır ve tutum da önemli bir göstergedir. Millet inşa etmenin önemli bir aracı olarak karşımıza çıkan müzik, bu bağlamda farklı bir sosyolojik içeriğe bürünmektedir.

Tablo 12. Türkiye'de Müzik İşiyle Uğraşanlar İçin Zorluk Derecesi

\begin{tabular}{||l|l|l||}
\hline Seçenekler & Yüzde & Sayı \\
\hline Fikrim Yok & 131 & $\% 20,5$ \\
\hline Maddi yönden yetersizlik & 139 & $\% 21,7$ \\
\hline Ciddiye alınmamaları & 127 & $\% 19,9$ \\
\hline Yeterli desteğin olmaması & 203 & $\% 31,8$ \\
\hline Diğer & 39 & $\% 6,1$ \\
\hline Toplam & $\mathbf{6 3 9}$ & $\mathbf{\% 1 0 0 , 0}$ \\
\hline
\end{tabular}


Katılımcıların verdikleri cevaplara bakıldığında, oranların birbirlerine yakın olduklarını ifade etmek mümkündür. Yeterli desteğin olmadığını belirtenlerin oranı \%31,8 iken, maddi yönden yetersizlik olarak belirtenlerin oranı ise $\% 21,7^{\prime}$ dir. Ciddiye alınmamaları seçeneği de $\% 19,9$ oranıyla belirtilen bir diğer yanıt olmuştur. Bir bütün olarak değerlendirildiğinde Türkiye'de birçok müzisyeninde yakındığı en önemli unsur "müziğe yeteri kadar maddi ve manevi desteğin verilmediği"nin, araştırmanın sonuçlarıyla desteklendiği belirtmek mümkün görünmektedir. Karabük Üniversitesi'nde yapılan çalışmada ise ortaya çıkan sonuçlarla ilişkili olarak gençlerin, üniversitede yaptıkları ya da yapmak istedikleri müzik etkinliklerine yeterli desteği bulamadıklarını belirtmiş olmaları da önemli bir detay olmuştur.

Tablo 13. Müzik Dinlemeyi Etkileyen Faktörlerin Dağılımı

\begin{tabular}{||l|l|l||}
\hline Seçenekler & Sayı & Yüzde \\
\hline Dinsel tutumlar (Müzik dinlemek günah ) & 85 & $\% 13,3$ \\
\hline Geleneksel tutumlar ( anne, baba etkisi ) & 63 & $\% 9,9$ \\
\hline Eğitim durumu ( Lise, Üniversite vb ) & 91 & $\% 14,2$ \\
\hline Çevresel faktörler( Yaşanılan yer, seyahatler vb ) & 206 & $\% 32,2$ \\
\hline Kişisel faktörler ( Arkadaş, iş arkadaşları vb. ) & 194 & $\% 30,4$ \\
\hline Toplam & $\mathbf{6 3 9}$ & $\mathbf{\% 1 0 0 , 0}$ \\
\hline
\end{tabular}

Müzik sosyolojik bir olgu olarak değerlendirilecekse, müzik dinlemeyi tek bir nedene dayandırmaktan ziyade birçok nedene dayandırmak daha anlamlı duracaktır. Katılımcıların verdikleri cevaplara bakıldığında, \%32,2'si müzik dinlemeyi çevresel faktörlerin etkilediğini düşünmüştür. Burada etkili olan çevresel faktörler; yaşanılan yer, seyahatler vb. olarak sıralanmıştır. Katılımcıların $\% 30,4$ 'ü ise müzik dinlemeyi etkileyen faktörlerin kişisel nedenlerden kaynaklandığını ifade etmiştir. Burada dikkat çeken en önemli faktör ise arkadaşlar olmuştur. Bir bütün olarak değerlendirildiğinde arkadaş ortamlarında dinlenen müzik parçalarının müzik tercihinde önemli bir etkisi olduğu görülmüştür.

Diğer oranlara bakıldığında katılımcıların \%14,2'si ise eğitim durumunun müzik dinlemede önemli bir faktör olduğunu belirtmiştir. Tercihler arasında eğitim durumunun müzik dinlemeyle ilişkisinin az olduğu gözlenmiştir. Katılımcıların \%13,3'ü din faktörünün etkili olduğunu belirtmiştir. Kuşkusuz burada günah faktörü yeniden gündeme gelmektedir. 
Geleneksel tutumlar seçeneğinin ise katılımcıların \%9,9 oranına denk geldiği görülmüştür. Burada geleneksel tutumların belirleyicisi olarak bireyin anne ve babası seçenek olarak sunulmuştur. Kuşkusuz ailede müziğe bakış açısı, gençlerin müzik ile ilgili algılarında önemli bir belirleyici olmaktadır. Müziğin günah olduğunu düşünen muhafazakâr/dindar bir aile içerisinde yetişen bireylerde "müziğin günah olduğuna dair düşünce ile" karşılaşılması daha muhtemeldir. Üniversite yıllarında görece "özgür" olduğunu varsayan gençler, müzikle ilişkili tutumlarında geçmiş bağlamlarından tam olarak kopmaları belirsiz durmaktadır.

Tablo 14. Okulumuzun Müzik Etkinliğini Yeterli Bulma Durumu

\begin{tabular}{||l|r|r||}
\hline Seçenekler & \multicolumn{1}{|l|}{ Sayı } & \multicolumn{1}{l|}{ Yüzde } \\
\hline Evet & 41 & $\% 6,4$ \\
\hline Hayır & 467 & $\% 73,1$ \\
\hline Kararsızım & 65 & $\% 10,2$ \\
\hline Fikrim yok & 66 & $\% 10,3$ \\
\hline Toplam & $\mathbf{6 3 9}$ & $\mathbf{\% 1 0 0 , 0}$ \\
\hline
\end{tabular}

Üniversitelere, müzik etkinliklerine öncülük etme konusunda önemli görevler düşmektedir. Bu görevler, müzik kurslarının organize edilmesi, şan eğitimi derslerinin hazırlanması, koroların oluşturulması, konser etkinliklerinin düzenlenmesi, amatör müzik gruplarının desteklenmesi gibi birkaç farklı başlıklarda sıralanabilir. Bu bağlamdan hareketle tabloya bakıldığında katılımcların \%71,3'ü Karabük Üniversitesi'nin müzik etkinliklerine yeteri kadar destek verdiğini düşünmedikleri görülmüştür. Katılımcıların sadece $\% 6,4^{\prime} \ddot{u}$ bu konuda üniversitenin verdiği desteği yeterli bulduğu görülmüştür.

Türkiye'de 2005 yılından sonra farklı bölgelerde ve Türkiye'de her şehirde bir tane olacak şekilde yeni üniversiteler kurulmuştur. Açlan üniversitelerin fiziksel (bina, altyapı, teknoloji vs.) özelliklerinin yanında sosyal ve kültürel bakımdan da hem şehri hem de içerisine giren bireyleri tatmin edebilmesi önemlidir. Ancak üniversitenin içerisinde bulunduğu şehirden kaynaklanan bazı yetersizlikler ve üniversitelerin çoğu zaman imkânlarının yetersizliği nedeniyle öğrencilerde sosyal ve kültürel çevreyle ilişkili bütünleşememe sorunları ortaya çıkmakta, bu durum çoğu zaman kendisinin serbest zamanlarda yapılabilecek hiçbir faaliyetin olmamasıyla ile (park, kafe, sosyal alan vb) kendisini göstermektedir. Böylece aslında belirgin bir şekilde karşımıza, serbest zamanı verimli kullanamayan bir üniversite öğrencisi profili çıkmaktadır. Öğrenciler, genellikle evlerde veya 
bilgisayar başında değerlendirdikleri bu serbest zamanda, sosyalleşmekten çok toplumdan soyut bir çevrenin içerisinde sanal bir gerçeklik yaratmaktadırlar.

Bu kapsamda üniversite bünyesindeki öğrencilerin sosyalleşmesini sağlayan ve serbest vakitlerinin değerlendirilmesini amaçlayan önemli oluşumlardan birisi öğrenci kulüpleridir. Kulüplerin öğrencilerin ortak girişimleriyle oluşturulması ve öğrenci bir merkezli kurumsallaşması da kulüpleri, üniversite alanı içerisinde öğrenciler açısından önemli kılmaktadır. Kulüpler hem öğrencilerin serbest zamanlarını etkin bir şekilde değerlendirmelerini sağlarken hem de kulüp yönetiminde bulunan öğrencilerin yöneticilik, girişimcilik gibi kişisel gelişimlerine de katkı sağlamaktadır. Ayrıca kulüp faaliyetlerinin öğrenci merkezli olmasından dolayı, kulüp faaliyetlerinin etkin hale gelmesi de öğrencilerle mümkün olmaktadır. Bunun yanında yeni üniversitelerde öğrencinin önünde yeterli örnek olmadığı için üniversite yönetimi, Sağlık, Kültür ve Spor Daire Başkanlığ1 ve akademik personel tarafından yapılan yönlendirmeler kulüp oluşumlarında önemli bir role (olumlu-olumsuz) sahiptir. Ayrıca öğrencilerin kulüp algısı bu oluşumların aktifleşmesinde etkilidir.

Karabük Üniversitesi, bölgede kurulmuş diğer yeni üniversitelerle kıyaslanınca öğrencilere sunduğu aktivite alanları bakımından oldukça üstündür. Özellikle öğrenci kulüplerinin çeşitliliği, sosyal ve kültürel aktivitelerin zenginliğini sağladığ sürecinde de önemli işlevler üstlenmiştir. Ancak müzik aktiviteleri ve konser gibi etkinliklere üniversitenin maddi desteği oldukça tartışmalıdır. Müzik icra etme konusunda amatör olarak çalışan grupların desteklenmesi ya da müzikle ilgili festival ve aktivitelerin yapılması konusunda üniversitenin desteğinin yeterli olmadığını söylemek mümkündür. Ancak üniversitenin kendi reklamını yapabildiği alanlarda "reklam olarak kullanabildiği her türlü aktivite" için sınırsız bir destek vermektedir. Kadın mehter takımının ${ }^{11}$ olması, "bizim için söyle"12 isimli proje ile üniversiteden seçilmiş akademisyen ve öğrencilerin türkü söylemesi, popüler sanatçıların mezuniyet törenlerine

\footnotetext{
${ }^{11}$ Karabük Üniversitesi tarafından kurulan "Ana Mehter Takımı" adlı ekip dünyada ilk kadın mehter takımı olma özelliği taşıyor.

12 Karabük Üniversitesi'nin ilk seslendirdiği türkü "Türkiyem" olmuştur. İkinci türkü ise "Dünyaca Söylenir, Türkümüz Bizim" olmuştur. Kuşkusuz Türkiye'de popüler bir kültürel pratiğin Karabük Üniversitesi tarafından da kullanılmış olması önemlidir. Öğrencilerin klipte rol almış olmaları, kurumsal anlamda çalışmada bahsi geçen "kurumsal değer katış" noktasında dikkat çeken önemli bir bağlamdır.
} 
getirilmesi ${ }^{13}$ ve halka açık konser etkinliği olarak düzenlenmesi, akademisyenlerden oluşan sanat müziği korosu bu aktivitelerden ön plana çıkanlarıdır.

Üniversitenin 3 Nisan Radyosu ile üniversite kampüsünde 24 saat kamuya açık yayın yapması da önemli bir aktive olmakla birlikte öğrencilerin "müzik konusunda üniversitenin desteğinin yeterli olmadı̆̆g" fikrinin etkilenmediği görülmektedir. Kuşkusuz burada en temel problem, kurumsal olarak üniversite adına yapılan her türlü aktivitelerde "bireysel olarak öğrenciye verilen değerin bizce yetersiz" olmasıdır. Öğrenciye bir "özne" olarak verilen değer, çoğunlukla kurumsal olarak ne kadar faydalı olduğu ile ilişkilidir. Üniversitenin "Biz Karabük Üniversiteliler" şeklinde kurumsallaşan önermesi de aslında burada doğrudan bireyi arka planda tutan ve bireysel olarak onu "silikleştiren" bir durumun dışa yansıması olarak göze çarpmaktadır. Ayrıca aynı önerme içerisinde öznenin üstünde otoriter bir alanın varlığı da dikkat çeken bir özellik olarak karşımıza çıkmaktadır. Bütün bu noktalar dikkate alındığında gençlerin, üniversite ile ilgili pozitif durumlarda bile "olumsuz değerlendirme" yaptığ1 görülmektedir.

Tablo 15. Okulumuzda Aktif Faaliyet Veren Herhangi Bir Müzik Kulübe Üyelik Durumu

\begin{tabular}{||l|r|r||}
\hline Seçenekler & \multicolumn{1}{|l|}{ Sayı } & \multicolumn{1}{l|}{ Yüzde } \\
\hline Boş & 3 & $\% 0,5$ \\
\hline Evet & 57 & $\% 8,9$ \\
\hline Hayır & 579 & $\% 90,6$ \\
\hline Toplam & $\mathbf{6 3 9}$ & $\mathbf{\% 1 0 0 , 0}$ \\
\hline
\end{tabular}

Müzik kulüplerine üye olmak bir müzik dinleyicisi için aktif bir faaliyet alanıdır. Bu açıdan ele alındığında katılımcıların \%96,6'sı üniversitede herhangi bir aktif faaliyet veren müzik kulübüne üye değildirler. Herhangi bir müzik kulübüne üye olanların sayısı ise $\% 8,9^{\prime}$ dur (Karabük Üniversitesi Müzik Kulübü). Kuşkusuz biraz önce kurumsal anlamda desteği yeterli bulmayan öğrencilerin, burada bireysel olarak

\footnotetext{
13 Türkiye'de üniversitelerin yaptığ 1 mezuniyet törenlerinde genellikle o dönem gençler arasında popüler olan sanatçlların davet edildiği ve törenin halka açık konser şeklinde devam ettirildiği görülmektedir. Örneğin 22 Ekim 2014 tarihinde Karabük Üniversitesinde "Illlerimiz Karabük Üniversitesi'nde Ay Yaldızın Altında Buluşuyor" projesi kapsamında Sıla konseri gerçekleştirilmiştir.
} 
özeleştiri yapmaları da kaçınılmaz olmaktadır. Çünkü öğrencilerin müzikle ilgili talep ve isteklerinin oldukça alt düzeyde olduğu görülmektedir.

Tablo 16. Yaşanılan Çevrenin Dinlenilen Müzik Üzerinde Etkisi

\begin{tabular}{||l|l|l|}
\hline \hline Seçenekler & Sayı & Yüzde \\
\hline Boş & 4 & $\% 0,6$ \\
\hline Kesinlikle katıllyorum & 132 & $\% 20,7$ \\
\hline Katıliyorum & 274 & $\% 42,9$ \\
\hline Kararsızım & 76 & $\% 11,9$ \\
\hline Fikrim yok & 29 & $\% 4,5$ \\
\hline Katılmıyorum & 94 & $\% 14,7$ \\
\hline Kesinlikle katılmıyorum & 30 & $\% 4,7$ \\
\hline Toplam & $\mathbf{6 3 9}$ & $\mathbf{\% 1 0 0 , 0}$ \\
\hline
\end{tabular}

Yaşanılan çevreninin müzik üzerinde önemli etkileri olabilmektedir. Müzik sosyal bir olgu olarak ele alındığında içinde bulunduğu toplum ile etkileşim içindedir. Bu durum daha önce Tablo 13'te gündeme getirilmişti. $\mathrm{Bu}$ bağlamdan hareketle değerlendirilecek olursa müzik, hiçbir şekilde yaşanılan çevreden bağımsız düşünülemez. Katılımcıların $\% 42,9^{\prime}$ u yaşanılan çevrenin dinlenilen müzik üzerinde etkili olduğuna katılmıştır. , \%20,7'si kesinlikle katılmıştır. Diğer oranlara bakıldığında "yaşanılan çeorenin müzik üzerine etkisi olduğu" önermesine katılımciların \%14,7'si sadece katılmamıştır, $\% 4,7^{\prime}$ si kesinlikle katılmıyorum şeklide kendilerini ifade etmişlerdir.

Tablo 17. Müzik Dinlerken Tercih Edilen Araç

\begin{tabular}{||l|l|l||}
\hline Seçenekler & Sayı & Yüzde \\
\hline Boş & 4 & $\% 0,6$ \\
\hline Radyo & 42 & $\% 6,6$ \\
\hline Televizyon & 34 & $\% 5,3$ \\
\hline Cep telefonu & 321 & $\% 50,2$ \\
\hline Mp3 çalar & 64 & $\% 10,0$ \\
\hline Bilgisayar & 162 & $\% 25,4$ \\
\hline Diğer & 12 & $\% 1,9$ \\
\hline Toplam & $\mathbf{6 3 9}$ & $\mathbf{1 0 0 , 0}$ \\
\hline
\end{tabular}

Gelişen teknoloji ile birlikte müzik dinleme araçları çoğalmıştır. Gedikli'ye göre (1984: 122), günümüz insanının ilgi alanı kitle iletişim 
araçlarının da etkisiyle çok genişlemiş̧ir. Aksu'ya göre (2002: 80) günümüz insanı, sanat müziklerinden halk müziklerine, caz müziğinden yığın müziklerine (pop ve hafif müzikler), deneysel müzik türlerinden eloktronsal müziğe kadar her tür müziğe ilgi duymakta ve bu türlerde de bilgi edinmek istemektedir. İnsanlar herhangi bir ezgiye teknolojinin yardımıyla daha kolay ulaşabilmişlerdir. Burada teknolojinin sağladığı yarar görmezden gelinemez.

Katılımcların verdikleri cevaplara bakıldığında ise cep telefonlarının \%50,2 ile diğer araçlardan daha fazla tercih edildiklerini görmek mümkündür. Diğer araçlardan daha fazla tercih ediliyor olması cep telefonun diğer araçlara oranla daha kolay taşınabilir ve daha pratik olması etkili olmaktadır. Kuşkusuz günümüzde gençlerin "akıllı telefon kuşă̆ı"nın olarak adlandırılması da bu bağlamda dikkate alınması gereken önemli noktalardan birisidir. Gençler artık bütün sosyal aktivitelerini akıllı telefonlar üzerinden gerçekleştirmektedirler.

Bilgisayarın ise $\% 25,4$ oranında tercih ediliyor olması günümüzde bilgisayarların neredeyse her evde olmasıyla artık hayatımızın bir parçası haline gelmesinde etkili olmasıyla ilgilidir. Özellikle sürekli bilgisayarla iç içe yaşan insanların yaşam alanlarında kuşkusuz bilgisayarların önemi büyüktür. Çok amaçlı bir biçimde kullanılan bilgisayarların müzik dinleme aracı olarak da kullanılması üzerinde durmamız gereken konulardan biridir. Katılımcıların MP3 çalarları \%10,6 oranında tercih etmeleri düşük bir rakamdır. Çünkü MP3 çalar yapısı itibariyle doğrudan müzik dinleme aracı olarak tasarlanmıştır. Ama katılımcılar tercih haklarını daha çok cep telefonu ve Bilgisayar üzerinden kullanmaktadırlar.

Tablo 18. Dinlenilen Müzik Tarzının Derslere Olumlu Katkı sunduğunu Düşünme

\begin{tabular}{||l|l|l||}
\hline Seçenekler & Sayı & Yüzde \\
\hline Boş & 4 & $\% 6$ \\
\hline Kesinlikle katıllyorum & 85 & $\% 13,3$ \\
\hline Katıllyorum & 154 & $\% 24,1$ \\
\hline Kararsızım & 113 & $\% 17,7$ \\
\hline Fikrim yok & 66 & $\% 10,3$ \\
\hline Katılmıorum & 144 & $\% 22,5$ \\
\hline Kesinlikle katılmıorum & 73 & $\% 11,4$ \\
\hline Toplam & $\mathbf{6 3 9}$ & $\mathbf{\% 1 0 0 , 0}$ \\
\hline
\end{tabular}


Katılımcıların \%24,1'i dinlenilen müziğin derslere olumlu katkı sunduğunu düşünürken, \%22,5'i dinlenilen müziğin derslere olumlu katkı sunduğuna katılmamıştır. \%17,7' si ise kararsız kalırken, \%13,3 kesinlikle katıldığını belirtmiştir. Kuşkusuz hızla değişen dünya karşısında gençlerin müzikle ilgili tutumlarının değişmesi ve güncellenmesi kaçınılmaz olmaktadır.

\section{Sonuç ve Değerlendirme}

Müzik yapma ve dinleme davranışı, kişilerin kendi tercihleriyle gerçekleştirdikleri bir eylemdir. Ancak bu eylem, sosyalleşme süreçlerinden bağımsız değildir ve bireylerin sosyal çevreleriyle yakından ilişkilidir. Böylece müzik, bireysel tutumlardan çok, sosyal gerçekliklere karşılık gelmekte ve sosyal yapıda önemli bir işlev üstlenmektedir. Kültürel değerler, ahlaki tutumlar, maddi gelir düzeyleri ve sınıf yapıları gibi birçok sosyal olgu, müziğin içeriğini ve müzik algısını tanımlamaktadır.

Araştırma, müziğin sosyolojik işlevselliğini dikkate alarak kimi zaman sosyal kimliklerle ilişkisini kimi zamanda bireylerin müzikle ilgili tutumlarında hangi faktörlerin ön plana çıktığını tartışmaya çalışmıştır. Çalışmanın çıkış noktası Karabük Üniversitesi öğrencileri olmuştur. Çalışmanın gizli kaygısı, "bir müzik sosyolojisi yapılmak istense hangi noktalar dikkat çekerdi?" sorusu üzerinden yürümüştür. Kimlikler ve müzik ilişkisi ise farklı sosyalliklerle gençlerin müzikle ilişkili kurguladıkları alanlara ulaşmayı amaçlamıştır. Araştırmada müziğin sosyolojik görüntüleriyle ilişkili ulaşılan sonuçları şu başlıklarda özetlemek mümkündür:

* Müzik, bütün demografik değişkenler (medeni durum, cinsiyet, gelir durumu, yaş, yaşanılan yer vb) dikkate alındığında hemen herkesin bir şekilde içerisinde olduğu bir alandır. Müziği toplumsal açıdan önemli kılan temel durum da kuşkusuz bu yaygın durumdur.

* Müzik; Sosyal ağlarla oldukça iç içe geçmiş bir alandır. Müzik, sosyo-kültürel yapıya dayalı bir sosyal davranışın sonucunda yaratılmaktadır. Bu nedenle müziği sadece bir ses sistemi olarak değil, kültürel yapının oluşturduğu, belli bir davranışın sonucunu da içinde taşımaktadır. Belli bir kültür içince yer alan sosyal bir olaydır. Üreten ve dinleyen o kültür içindeki insanlardır. Besteler, o kültürdeki insanların davranışlarının yansımasıdır. Kültürü tanımadıktan sonra şarkıların sözleri ve anlatmak istedikleri tam olarak anlaşılmayacaktır.

* Teknolojik yenilikler, müzik dinlemenin ve müzikle ilgilenmenin biçimlerini güncellemektedir. Bu güncellemeler, özellikle genç kuşağın kaçınılmaz olarak içerisine girdiği bir alandır. Küresel değişimler de bu süreçleri beslemektedir. 
* Konserler, festivaller ve benzer aktiviteler, öğrencilerin farklı insanlarla aynı amaç için buluştukları sosyal ağların adı olmaktadır. Bu ağlar, aynı zamanda tek bir sosyal kimlik altında toplanan bireylerin sosyal durumlarını da tanımlamaktadır. Karabük Üniversitesi'nde yapılan konser etkinlikleri, halk ile öğrencileri bir araya getiren bir alan da olduğu için bu sosyallikler farklı biçimlerde yeni toplumsal durumları ortaya çıkarmaktadır ya da kent-üniversite etkileşiminde yeni bir sosyalliğe kaynaklık etmektedir. Kuşkusuz, yeni üniversitelerin kuruldukları şehirde yarattığı gelişme alanları dikkate alındığında, bu tür etkinliklerin müziğin sosyolojik gücünü göstermesi bakımından araştırmacılar tarafından önemli bulunmuştur.

* Araştırmada, öğrencilerin demografik durumlarıyla dinledikleri müzik tarzları arasında doğrudan bir ilişki kurulmuştur. Özellikle kendisini muhafazakâr veya milliyetçi olarak tanımlayanların halk müziği gibi yerel müzikleri daha çok tercih ettikleri, sosyal demokrat olarak kendilerini tanımlayanların ise daha Batı tipi müzikler dinledikleri tespit edilmiştir. Ayrıca kadınların, erkeklere göre pop müzik tercih etmek oranlarl; erkeklerin de kadınlara göre arabesk müzik dinleme tercihlerinin yüksek oranda olduğu tespit edilmiştir.

* Gençlerin müzikle ilişkili kurdukları etkileşimde en belirgin noktalardan biri de kafeler kültürünün, önemli bir serbest zaman aktivitesi olarak gözlemlenebilir olmasıdır. Özellikle Karabük Üniversitesi'nin yeni bir üniversite olması ve şehrin üniversiteye ayak uydurma çabaları sonucunda ortaya çıkan en önemli değişimler sosyal aktivite alanlarında gerçekleşmiştir. Üniversite mahallesinde başlayan kafe kültürü, gençlerin uğrak mekânları olmakla birlikte, müziğin etkili bir şekilde kullanıldığı sosyal bir boyutun da ortaya çıkışına kaynaklık etmiştir.

* Küreselleşmenin getirdiği kitlesellikler karşısında, yerel kültürel değerlerin korunma çabaları müzik tercihlerine de yansımıştır. Folklorik müzik temaları ön plana çıkmakla birlikte, milli marşlar ve Türk sanat müziği de ön plana çıkan araçlardan birisi olmuştur. Siyasal iktidarın Osmanlı Devleti ile kurmuş olduğu temas, Osmanlı ezgilerinin de ön plana çıkışına zemin hazırladığı gibi mehteran olgusunun da günümüzde sürekli gündeme geldiği görülmektedir. Karabük Üniversitesi'nin kadın mehteran takımıyla da bu sürece ayak uydurduğu tespit edilmiştir.

Sonuç olarak müzik, sosyolojik olarak değerlendirildiğinde birkaç farklı kategoriye denk düşebilmektedir. Bireysel tercihler söz konusu olduğunda müzik, sosyal bağlamlardan kopuk değildir. Sosyal tercihler söz konusu olduğunda müzik, yeni sosyal ağların oluşmasında bir araç haline dönüşebilmektedir. Son olarak küreselleşme karşısında bireylerin siyasi ve 
kültürel olarak kendilerini ifade ettikleri alanların birisini ifade edebilmektedir.

\section{Kaynakça}

AKAY, Ali vd. (1995); İstanbul'da Rock Hayatı - Sosyolojik Bir Bakış, İstanbul: Bağlam Yayınları.

ARISTO (1975); Politika, Çev: Mete Tunçay, İstanbul: Remzi Kitabevi.

BAUMAN, Zygmunt (2003); Modernlik ve Müphemlik, çev: İsmail Türkmen, İstanbul: Ayrıntı Yayınları.

BENNETT, Andy (2006); "Subcultures or Neo-tribes? Rethinking the Relationship between Youth, Style and Musical Taste", in Bennet, A; Shank B; Tonbree, J. (Ed) The Popular Music Studies Reader, London: Routledge.

COOK, Nicholas (1999); Müziğin ABC'si, Çev: Turan Doğan, İstanbul: Kabalcı Yayınevi.

COVINGTON, H. (2001); "Therapeutic Music for Patients with Psychiatric Disorders", Holistic Nursing Practice, Vol: 15 (2), pp.59-69.

EROL, Ayhan (2002); Popüler Müziği Anlamak: Kültürel Kimlik Bağlamında Popüler Müzikte Anlam, İstanbul: Bağlam Yayınları.

GENÇEL, Özge (2006); “Müzikle Tedavi”, Kastamonu Eğitim Dergisi, Cilt: 14, No:2, ss.697-706.

GÜNGÖR, Nazife (1993); Arabesk, Ankara: Bilgi Yayınevi.

IŞIK, Caner; EROL, Nurdan (2002); Arabeskin Anlam Dünyası, İstanbul: Bağlam Yayıncıları.

KAPLAN, Ayten (2005); Kültürel Müzikoloji, İstanbul: Bağlam yayınları.

LÜKÜSLÜ, Demet (2011); “Ulusaşırı Bir Gençlik Kültürü ve Toplumdan Sayg1 Talebi Olarak Hip-Hop", Toplum ve Bilim, sayı:121, ss.201222.

MAFFESOLI, Michel (1996); The Time of The Tribes: The Decline of Individualism in Mass Society, London: SAGE Publications Ltd.

NACAKÇI, Zeki ve KURTULDU, M. Kayhan (2000); Kuramdan Uygulamaya Müzik Eğitiminde Yeni Yaklaşımlar, Ankara: Anı Yayincilik.

ÖZ, Nesrin Biber (2001); “İnsanın Kültürel Gelişiminde Müzik Eğitiminin Önemi", Uludağ Üniversitesi Eğitim Fakültesi Dergisi, Cilt: XIV, Say1:1, Bursa, ss.101-106.

ÖZBEK, Meral (2012); Popüler Kültür ve Orhan Gencebay Arabeski, İstanbul: İletişim Yayınları. 
PLATON (1975); Devlet, çev: Sabahattin Eyüboğlu, M. Ali Cimcoz, İstanbul: Remzi Kitabevi.

ROWE, David (1996); Popüler kültürler: Rock ve Sporda Haz Politikası, çev: Mehmet Küçük, İstanbul: Ayrıntı Yayınları.

SAĞIR, Adem ve AL, Mustafa (2007); "Postmodern Sosyalleşme Sürecinde "Rock" Müzik ve "Rocker"lar: Sakarya Örneği", Sosyoloji Yazıları I, İstanbul: Kızıl Elma Yayınları.

SAĞIR, Adem ve İNCI, Ülkü H. (2013); “Karabük'te Üniversite Alg1sı: Karabük Üniversitesi Örneği", İTOBİAD, Cilt:2, Sayı:2, ss.49-81.

SELANIK, Cavidan (1996); Müzik Sanatının Tarihsel Serüveni, Ankara: Doruk Yayımcllı.

SENNETT, Richard (2005); Karakter Aşınması- Yeni Kapitalizmde İşin Kişilik Üzerinde Etkileri, çev: Barış Yıldırım, İstanbul: Ayrıntı Yayınları.

SOMAKCI, Pınar (2003); “Türklerde Müzikle Tedavi”, Erciyes Üniversitesi Sosyal Bilimler Enstitüsü Dergisi, Say1: 15, Cilt:2, ss.131-140.

SOYKAN, Ömer Naci (2002); “Müzik Estetiği”, Cogito Dergisi, Sayı:30, İstanbul, Yapı Kredi Yayınları,.

STOKES, Martin (1998) ; Türkiye'de Arabesk Olayı, Çev: Hale Eryılmaz, İletişim Yayınları, İstanbul.

ŞENOCAK, Emel (2005); "Müziğin İnsan Yaşamındaki Yeri", Müzik Sempozyumu, E.Ü. Kayseri, Nisan14-16, ss.270-279.

UÇAN, Özlem ve OVAYOLU, Nimet (2006); “Müzik ve Tipta Kullanımı", Fırat Sağlık Hizmetleri Dergisi, Cilt: 1, Sayı: 3, ss.14-22.

URAL, Ayhan ve KILIÇ, İbrahim (2011); Bilimsel Araştırma Süreci ve SPSS İle Veri Analizi, Ankara: Delta Yayıncılık.

WARDE, Alan (2005); "Consumers, Identity and Belonging Reflections on Some Theses of Zygmunt Bauman", (iç) The Authority of The Consumer, ed. Russel Keat, Nigel Whiteley and Nicholas Abercrombie, London: Routledge, pp.53-68.

WOODY, Robert H. (2007); "Popular Music in School: Remixing the Issues", Music Educators Journal, Vol: 93, No: 4, pp.32-37.

YELKEN, Ramazan (1999); Cemaatin Dönüşümü- Geç Modern Dönemde Cemaat Sosyolojisi, Ankara: Vadi Yayınları. 